\title{
FEDERALISM AND THE AMERICAN ECONOMIC ORDER, 1789-1910
}

\author{
HARRY N. SCHEIBER* \\ University of California, San Diego
}

From the beginning of nationhood under the Constitution to the present day, the federal system of American governmentwhat Madison termed "a novelty and a compound," and what Hamilton declared was "necessarily a compromise of dissimilar interests and inclinations"1-has been of profound importance in shaping the nation's economic order. Power has shifted over time between the national government and the constituent state governments; and these structural shifts have had an impact upon policy process and outcomes, as well as upon the economy's institutional framework. The study of federalism has long been, of course, a concern of scholarship in constitutional law, political science, and history. Moreover, historians of American politics have lavished much attention upon the great conflicts of interest groups, parties, and ideologies, from 1787 to the New Deal and after, over the basic question of the extent to which power ought to be centralized in our federal system. ${ }^{2}$ And yet no scholarly

- The author thanks the John Simon Guggenheim Memorial Foundation, the Center for Advanced Study in the Behavioral Sciences, and the University of California for support of research from which this study derives. A briefer, preliminary version of this article was prepared as a paper for the Sixth International Congress, Association Internationale d'Histoire Economique, in Copenhagen.

The author is much indebted to Professor Lawrence Friedman of Stanford University for close reading and criticism of the manuscript. Professors Friedman, Paul W. Gates (Cornell University), and Willard Hurst (University of Wisconsin) have offered many valuable suggestions during the course of research for this monograph, over several years. The author is solely responsible, however, for the work's content and interpretations.

1. James Madison to N.P. Trist (Dec. 1831) Records of the Federal Convention of 1787, III, 517 (Farrand ed., 1937 revision); Alexander Hamilton, The Federalist, No. 85, 591 (Cooke ed. 1961). For the abiding ambiguities of the 1787 compromises, cf. Alpheus T. Mason, "The Supreme Court and Federalism," 44 Tex. L. Rev. 1187, passim (1966); and Alpheus T. Mason, "The Federalist: A Split Personality," $57 \mathrm{Am}$. Hist. Rev. 125 (1952).

2. See William H. Riker, Federalism: Origin, Operation, Significance (1964); and two important collections of essays, American Federalism in Perspective (Wildavsky ed. 1967); and Federalism, Mature and Emergent MacMahon ed. 1955). Federalism as a working system is considered from sharply divergent perspectives in Harry $\mathbf{N}$. Scheiber, The Condition of American Federalism: An Historian's View (89th Cong., 2d Sess., Senate Committee on Government Operations, committee print, 1966); and Daniel Elazar, The American Partnership (1962). See also Morton Grodzins, The American System (Elazar ed. 1966). Cf. Roy F. Nichols, American Leviathan: The Evolution and Progress of Self-Government in the United States (Harper Colophon edition, 1966). 
studies have been specifically devoted to the analysis of federalism as an institutional variable both influencing the development of enterprise in the private sector and influencing economicpolicy processes and the substance of public economic policy. This paper attempts such an analysis. Part I reviews the recent literature on law and economic history, and Part II considers some theoretical issues. Parts III and IV examine historic American federalism in relation to governmental institutions and power, public economic policies, and the dynamics of the economy's private sector.

\section{SCHOLARLY PERSPECTIVES ON FEDERALISM AND PUBLIC POLICY}

Recent lines of research in the field of legal-economic history-as well as in sister fields of economic, administrative, and constitutional history-have produced important, fresh perspectives upon the character and functions of public economic policy from the nation's founding to the early 20 th century.

The field of legal-economic history, led and exemplified by the scholarship of Willard Hurst, ${ }^{3}$ does not spring from an intellectual void. It has built, in the first place, upon the solid foundation of numerous monographs in institutional economic history in the last thirty years-especially upon the work of historians and economists who have given close study to the economic programs of 19 th century American state government. Thus, the well-known studies sponsored by the Council on

The problem of federalism is also probed imaginatively by Lawrence Friedman in his major synthesis, $A$ History of American Law (1973). See note 28, infra.

3. Cf. Harry N. Scheiber, "At the Borderlands of Law and Economic History: The Contributions of Willard Hurst," 75 Am. Hist. Rev. 744 (1970); Earl F. Murphy, "The Jurisprudence of Legal History: Willard Hurst as a Legal Historian," 39 N.Y.U.L. Rev. 900 (1964). What is said here is not intended to minimize the scholarly importance of contributions to legal history bearing on economic questions in the field of colonial studies. Particularly fruitful was the type of inquiry opened up by Richard B. Morris, in his Studies in the History of American Law (1930; 2 d ed. 1959) and examplified by his magnum opus Government and Labor in Early America (1946). The spurious criticism that Hurst and numerous other recent writers in legal-economic history tend to accept "as uniformly benign" the type of material growth (with its social costs) that occurred in the 19th century, and tend to adopt and "mirror" what are termed "19th-century majoritarian ideological attitudes," is made in an otherwise valuable bibliographic survey by Wythe Holt, "Then and Now: The Uncertain State of Nineteenth-Century American Legal History," 7 Ind. L. Rev. 615, 623-24 (1974). Another important bibliographic essay is Lawrence M. Friedman, "Some Problems and Possibilities of American Legal History," in The State of American History 2 (Bass ed. 1970). An excellent critical survey of colonial legal studies is provided by Herbert A. Johnson, "American Colonial Legal History," in Perspectives on Early American History 250 (Vaughan \& Billias eds. 1973). 
Research in Economic History discredited the once-popular myth of laissez-faire government in the 19th century. Mainly through analysis of the history of legislation and ideological conflicts in the states, these studies supplied the evidence for viewing 19 th century state governments as interventionist. To be sure, there is still some disagreement over the degree to which the states' interventions supported private entrepreneurial aspirations and interests, or instead autonomously defined and pursued "commonwealth" goals. And, as monographic study of individual states has shown, the relative importance of promotional and of regulatory features in a particular state's program of economic policies may often have depended upon the state's stage of economic development or upon other local-situational factors." Whatever the remaining interpretive questions, however, the monographic studies of state policy-like the studies of American land policy pioneered by Paul W. Gates some years earlier-disposed of the myth that the range and impact of 19 th century governmental interventions had been only minimal. ${ }^{5}$ Moreover,

4. Studies of state government and economic policy, and their implications for a revisionist view of state activism, were considered in Robert A. Lively, "The American System: A Review Article," 29 Bus. Hist. Rev. 81 (1955), then reappraised in the light of more recent scholarship in Harry N. Scheiber, "Government and the Economy: Studies of the 'Commonwealth' Policy in 19th-Century America," 3 $J$. Interdisc. Hist. 135 (1972). Among the leading studies in the field are Carter Goodrich, Government Promotion of American Canals and Railroads, 1800-1890 (1960); Oscar Handlin \& Mary Flug Handlin, Commonwealth: A Study of the Role of Government in the American Economy: Massachusetts, 1774-1861 (rev. ed. 1969); Louis Hartz, Economic Policy and Democratic Thought: Pennsylvania, 1776-1860 (1948); Milton Heath, Constructive Liberalism: The Role of the State in the Economic Development of Georgia to 1860 (1954); Gerald D. Nash, State Government and Economic Development ... in California (1964); Stephen Salsbury, The State, The Investor, and The Railroad: The Boston \& Albany, 1825-1867 (1967); and Harry N. Scheiber, Ohio Canal Era: A Case Study of Government and the Economy, 1820-1861 (1969), hereinafter Scheiber, Ohio Canal Era. By the 1960s such studies were much influenced by the work of J. Willard Hurst, especially Law and the Conditions of Freedom in the Nineteenth Century United States (1956), hereinafter Hurst, Law and the Conditions of Freedom; Law and Social Process in United States History (1960), hereinafter Hurst, Law and Social Process; and Law and Economic Growth: The Legal History of the Lumber Industry in Wisconsin 1836-1915 (1964), hereinafter Hurst, Law and Economic Growth. Whereas Hurst's work centered on resource-allocative policies, private contract, and franchises, the focus of studies in states which (unlike Wisconsin) undertook major public enterprises in the transport field tended to stress the importance of internal-improvements policy. (See especially the works by Hartz on Pennsylvania, Salsbury on Massachusetts, and Scheiber on Ohio, supra, this note.)

A reappraisal of transport policies is provided in two articles by Carter Goodrich, "Internal Improvements Reconsidered," $30 \mathrm{~J}$. Econ. Hist. 295-98 et passim, and "State In, State Out: A Pattern of Development Policy," 2 J. Econ. Issues 365 (1968).

5. Cf. Paul W. Gates, History of Public Land Law Development (1968); and Thomas H. Le Duc, "History and Appraisal of U.S. Land Policy to 1862," in Land Use Policy and Problems in the United States 3 (Ottoson ed. 1963). 
the literature on the state governments' economic roles provided an indispensable basis for new lines of work by scholars in the legal-economic historical mode.

In the second place, legal-economic history exploited (and also inspired) studies of governmental bureaucracies and their impact upon the entrepreneurial environment of the 19th century. This sort of historical research depended upon the discovery and analysis of administrative archives, to augment research in the published reports of state and federal agencies; and it revealed dimensions of public power and its uses that had been only dimly seen so long as scholars had confined their research to the study of statutes. It was no surprise that the early bureaucracies were found to have been enmeshed in varying degrees of humdrum activity, doing the day-to-day business of government. But the new studies also revealed-quite contrary to the established view-that some federal agencies were engaged in innovative activities that went far beyond "mere administration." (Most notably, the Army Engineers, who made major contributions to the planning and execution of large-scale transportation projects.) And once even a few state governments had been studied in detail, it became evident that we had to redefine the staple analytic concepts of "public enterprise" and "state regulation" to take account of an activist officialdom. The states relied heavily upon devoted amateurs or personnel trained on the job, without large salaried staffs or, in many instances, what modern analysts would regard as minimal bureaucratic organization; and yet their lean bureaucracies were capable of extending the reach and impact of public power beyond what a mere reading of statutes would remotely suggest. ${ }^{6}$ Again, the

6. See esp. Scheiber, Ohio Canal Era; Nathan Miller, The Enterprise of a Free People: Aspects of Economic Development of New York State During the Canal Period 1792-1838 (1962); Nash, supra, note 4; and Ralph D. Gray, The National Waterway: A History of the Chesapeake and Delaware Canal 1769-1956 (1967).

Leonard $\mathrm{D}$. White provided a magisterial survey of the federal bureaucracy in The Federalists: A Study in Administrative History 1789-1801 (1948) and succeeding volumes on the Jeffersonians, the Jacksonians, and the Republicans. But for a probing into the impact of federal officialdom on significant economic interests and on the development of private-sector institutions, the most important work (apart from that of Gates on land disposal) is Forest G. Hill, Roads, Rails, and Waterways: The Army Engineers and Early Transportation (1957). Other useful studies of federal agencies include $W$. Turrentine Jackson, Wagon Roads West: A Study of Federal Road Surveys and Construction in the Transmississippi West 1846-1869 (1952); Malcolm Rohrbough, The Land Office Business: The Settlement and Administration of American Public Lands 1789-1837 (1968); and, for the late 19th century, Leslie E. Decker, Railroads, Land, and Politics: The Taxation of the Railroad Land Grants 1864-1897 (1964); and Samuel P. Hays, Conservation and the Gospel of Efficiency: The Progressive Conservation Movement 1890-1920 (1959). 
verdict is not yet in as to whether officials' activism was essentially supportive of private-sector interests, or instead an autonomous assertion of "public interest" goals. But the range and significance of activism cannot be gainsaid. Moreover, the emergent portrait of innovating bureaucracies raised important new questions pertinent to the concerns of scholars who were re-examining judicial doctrines and their effects in the 19th century-especially questions concerning the conflicts of "have" and "have-not" substate regions that could struggle over transport or bank-credit policy as effectively before administrative agencies as in the courts or in the legislature, or questions concerning the allocation of special advantages and immunities to some types of enterprise at the expense of others. ${ }^{7}$

Finally, the intellectual foundations of the new legal economic history owe much to the tradition of Legal Realism in American jurisprudence. For Legal Realism and legal-economic history both have conceptualized law as a working system, responding to market-place pressures and serving real interests, instead of viewing law as a corpus of abstract doctrine. Roscoe Pound's distinction between "law in books and the law in action" thus became a basic operative premise of both the realists and the new historians. ${ }^{8}$ As is true of Legal Realism, the new legaleconomic history is, however, peculiarly vulnerable to reductionist fallacies-the danger, above all, of denying the importance of ideas or even major ideologies as determinants of political (and judicial) behavior. ${ }^{9}$ Indeed, because they have the advantage

The major canal states raised millions of dollars through bond issues for their construction programs. Nathan Miller, supra, this note, was first to recognize the importance of these funds as they were managed by state officials for larger developmental purposes: the New York commissioners consciously placed the funds in state banks as a means of expanding bank credit, also using accruing canal revenues for related purposes. A variant of the same type of activist policy by administrative officials in another state is explored in Harry N. Scheiber, "Public Canal Finance and State Banking in Ohio 1825-37," 55 Ind. Mag. Hist. 119-32 (1969).

7. Cf. Scheiber, Ohio Canal Era at 61-87, 354-68; George H. Miller, Railroads and the Granger Laws (1971); Harry N. Scheiber, "Public Policy, Constitutional Principle, and the Granger Laws," 23 Stan. L. Rev. 1029 (1971).

Cf. Gerald D. Nash, "Government and Business: A Case Study of State Regulation of Corporate Securities, 1850-1933," 38 Bus. Hist. Rev. 144 (1964); Edwin Patterson, The Insurance Commissioner in the United States (1929); Walter K. Ferguson, Geology and Politics in Frontier Texas 1845-1909 (1969).

8. Pound, "The Law in Books and Law in Action," 44 Am. L. Rev. 12 (1910). Cf. Pound, Interpretations of Legal History (1923); and Johnson, supra, note 3 , at 255-57. The relationship between Pound's theories and those of the Realists is delineated imaginatively in Wilfrid Rumble, Jr., "Law as the Effective Decisions of Officials: A 'New Look' at Legal Realism," 20 Jnl. Pub. L. 215, 237ff (1971).

9. See Friedman, supra, note 3. 
of hindsight with respect to Legal Realism and its travails, historians in the newer mode are probably over- rather than under-sensitized to the perils of reductionism.

Whatever the intellectual pitfalls of legal-economic history, research in this mode has at least avoided the sort of problems generated by the so-called New Economic History-a line of scholarship that has developed contemporaneously with the new legal-economic studies, and similarly in formal (if not always truly functional) association with the main tradition of economic history. ${ }^{10}$ For the New Economic History stressed the need for quantification and the use of models and theory drawn from contemporary economics. In so doing, its practitioners-at least in its worst days, now fortunately past-often cavalierly treated institutions as a "given." Consequently, they regarded market factors as entirely controlling; and-in an ironic variant of reductionism-they conceived not only of law but also the entire institutional structure of the society as responding mechanistically to the imperatives of supply and demand forces in the marketplace. ${ }^{11}$

Instead, legal-economic history has sought to reappraise the content of statutory and judge-made law, and also to assess the

10. For summaries of research in, respectively, the mode of the New Economic History and that of institutional economic history, cf. two useful bibliographic-analytic surveys: Albert Fishlow and Robert W. Fogel, "Quantitative Economic History: An Interim Evaluation," 31 J. Econ. Hist. 15 (1971); and James H. Soltow, "American Institutional Studies: Present Knowledge and Past Trends," 31 J. Econ. Hist. 87 (1971).

11. A penetrating critique is provided by Harold D. Woodman, Jr., in "Economic History and Economic Theory: The New Economic History in America," 3 J. Interdiscip. Hist. 323 (1973). A useful journalistic analysis, centering on a recent study of slavery is Constance Holden, "Cliometrics," 186 Science 1004 (1974); cf. Harry N. Scheiber, "Black Is Computable," 44 The American Scholar 656 (1975).

Recently one of the most prominent of the scholars who innovated the New Economic History has written that neo-classical theory, which is the most important tool of analysis in this mode, (1) "was not designed to explain long-run economic change;" and (2) "is immediately relevant to a world of perfect markets-that is, perfect in the sense of zero transaction costs: the costs of specifying and enforcing property rights. Yet we have come to realize that devising and enforcing a set of rules of the game is hardly ever costless and the nature of these costs is at the very roots of all economic system's [sic] problems. Accordingly, a theoretical analysis of the changing rules of the game is at the very core of the subject matter of economic history." Douglass C. North "Beyond the New Economic History," 34 J. Econ. Hist. 1, 3 (1974). Unfortunately North did not pursue this theme with reference to studies such as those of Willard Hurst which make their main theme precisely these "changing rules." Cf. Peter D. McClelland, Causal Explanation and Model Building in History, Economics, and the New Economic History (1975). The new economic history at its best is exemplified in the brilliant study by Jeffrey G. Williamson, Late Nineteenth Century Economic Development: A General Equilibrium History (1974). Cf. Approaches to American Economic History (Taylor \& Ellsworth eds. 1973). 
mode of decision-making and policy formulation in the legal system as a whole, in order to define the causal relationships between law and socio-economic change. Thus, in the work of Willard Hurst, doyen of the field, we find legislatures and courts of the 19th century states subjected to fresh analysis designed to extract the substantive essence of law and public policy. Beyond that, Hurst's studies have given these law-making agencies searching critical analysis. Implicitly postulating a normative model of a rational, responsible legal system that investigates facts, articulates options, weighs the alternatives, and wields governmental power with probity and the effectiveness derived from sufficient fiscal and administrative resources-a model, as it were, of Brandeisian juridical principle-Hurst concludes that the courts and legislatures of the 19th century failed to attain and assert a purposeful autonomy. ${ }^{12}$

A second major finding of work in the Hurst mode is that U.S. society relied heavily upon private contract in the 19th century to release, or liberate, "private energies" toward the end of maximizing economic growth. Incorporating the results of studies (mentioned earlier) of the state governments and their bureaucracies, the newer scholarship finds a large element of conscious resource allocation by government-operating through the processes both of common law and of public law and its administration. Not only through the mechanism of private contract but also through bold juridical innovation, the states introduced new doctrines that often displaced vested property interests in order to expedite technological change and economic development. Hurst's studies, the work of Lauer and Horwitz on riparian law, my own on eminent domain law and the public purpose doctrine, Nelson's on judicial reasoning, and Friedman and Ladinsky's on the law of industrial accidents, have all considered the 19th century judiciary as having made significant "intangible" contributions to capital formation. ${ }^{13}$ Thus judges

12. See the analyses of Hurst's main themes, in articles by Scheiber and by Murphy, supra, note 3 .

13. T.E. Lauer, "The Common Law Background of the Riparian Doctrine," 28 Mo. L. Rev. 60 (1963) ; Morton J. Horwitz, "The Transformation in the Concept of Property in American Law 1780-1860," 40 U. Chi. L. Rev. 248 (1973); Harry N. Scheiber, "The Road to Munn: Eminent Domain and the Concept of Public Purpose in the State Courts," Law in American History 327 (Fleming \& Bailyn eds. 1972); William E. Nelson, "The Impact of the Antislavery Movement upon Styles of Judicial Reasoning in 19th Century America," 87 Harv. L. Rev. 513 (1974); Harry N. Scheiber, "Instrumentalism and Property Rights," 1975 Wisc. L. Rev. 1. A study richly suggestive of how judges fashioned law to transfer some major costs of industrialization to individuals or the community (to the advantage of entrepreneurs) is Lawrence Friedman and Jack Ladinsky, "Social Change and the Law of Industrial Accidents," 67 Colum. L. Rev. 50 (1967). 
mobilized boldly creative expediting doctrines to reduce entrepreneurial costs for mill-dam builders, canal and railroad promoters, miners, lumbering companies, and other types of private firms. ${ }^{14}$ Moreover, these judicial expediting doctrines, abridging vested property rights and creating new ones, were a complement to other tangible contributions by government to capital formation. Among these others were the creation of franchises, the granting of exemptions and privileges to corporations, and the benevolent types of police-power regulations that helped to establish economic priorities and advance desired types of development. ${ }^{15}$ In addition, it is well to recall that the usury lawsvarying greatly in their terms, from one state to another-also were designed to expedite capital formation, although they nonetheless may have served also to impede investment in certain situations. ${ }^{16}$ Intangible contributions of this sort supplemented the tangible ones by the state and federal governments in the form of transportation investments-both in cash and in grants of land beginning in the canal period of the 1820 s and continuing throughout the century. ${ }^{17}$

Furthermore, recent research in legal-economic history and related branches of historical study has explored the slippery question of popular beliefs and normative values that (variously) advanced or stood in the way of economic development. This vexing subject, long a subject of historians' concern, has been cast in a new light by work such as Hurst's and Friedman's on the style of 19th century lawmaking that supported and reflected

14. Cf. Harry N. Scheiber, "Property Law, Expropriation and Resource Allocation by Government 1789-1910," 33 J. Econ. Hist. 232 (1973).

15. The full range and impact of these interacting policies is examined in rich detail in Hurst, Law and Economic Growth. See also Harry N. Scheiber and Charles McCurdy, "Eminent Domain Law and Western Agriculture," 49 Agric. Hist. 112-30 (1975); and Charles McCurdy, "Stephen J. Field and Public Land Law Development in California, 1850-1866: A Case Study of Judicial Resource Allocation in Nineteenth Century 10 Law \& Society Review, forthcoming.

16. On usury laws and their impact, a much-neglected subject, cf. Lawrence M. Friedman, "The Usury Laws of Wisconsin: A Study in Legal and Social History," 1963 Wisc. L. Rev. 515, which is the only adequate state-level scholarly study available; and a brief but valuable, suggestive discussion of the New York usury law's effects on investment, in Alan L. Olmstead, "New York City Mutual Savings Banks Portfolio Management and Trustee Objectives," $34 \mathrm{~J}$. Econ. Hist. 815, 824-29 (1974). There was, of course, much blatant evasion of usury restrictions. Cf. Robert Swierenga, Pioneers and Profits: Land Speculation on the Iowa Frontier, 151-52, 152n. (1968). See also Hurst, Law and Economic Growth, at 469-70; and Allan G. Bogue, Money at Interest: The Farm Mortgage on the Middle Border (1955).

17. Cf. Gates, supra, note 5; Harry N. Scheiber, "State Policy and the Public Domain: The Ohio Canal Lands," 25 J. Econ. Hist. 86 (1965); William S. Greever, "A Comparison of Railroad Land-Grant Policies," 25 Agric. Hist. 83 (1951). 
popular faith "in the beneficent dynamics of increased productivity."18 It is now well accepted that the "style" of judicial law-making, at least before 1860 , was predominantly instrumental, reflecting pragmatic concern to advance productivity and material growth. And even in the late 19th century, when legal formalism held sway in many areas of the law, the instrumental style persisted in the vital area of property law and perhaps to no less degree in tort law. ${ }^{19}$

Hurst and others may be faulted on this count, I think, for a sometimes too-ready assumption that because the goal of material growth and a style of "drift and default" were both emblematic of resource allocation by the 19 th century legal system, ${ }^{20}$ it follows that the law reflected the actual Volksgeist, let alone specific policy preferences, of the society generally. For there was abundant ideological conflict in the society. Moreover, one cannot easily relegate to obscurity the effects of outright corruption affecting legislatures and judges. Nor ought we to risk underrating the possibility that judges may have engaged themselves in conscious obscurantism when they clothed new doctrines-doctrines that well served particular entrepreneurial interests-in the traditional rhetoric of the common law. ${ }^{21}$ Venality and deviousness, perhaps no less than drift and default, also demand some measure of recognition in any plausible model of 19 th century lawmaking. ${ }^{22}$

Finally, the new institutional and legal-economic historical

18. Hurst, Law and Social Process 236; cf. Friedman, supra, note 2.

19. Scheiber, supra, note 14, at 243-51.

20. Hurst, Law and Economic Growth, 123, 262-70.

21. Sorting out the ingenuous adaptations of traditional doctrine from the disingenuous (or obscurantist) is no easy task in the analysis of 19 th-century judicial law-making. See, e.g., Scheiber, "The Road to Munn," supra, note 13; Nelson, supra, note 13; and the critique of Nelson's view in Scheiber, "Instrumentalism and Property Rights," supra, note 14. The most productive approach to this problem, I think, probably lies in a biographical mode of analysis. A major work that pursues this mode is the classic study by Leonard W. Levy, The Law of the Commonwealth and Chief Justice Shaw (1957).

22. Thus Gilman Ostrander, Nevada: The Corrupt Borough 30-34 (1966) chronicles a mining-law case of first importance whose outcome was apparently decided on the basis of minutely calibrated bribes, ranging up to $\$ 60,000$ for the territory's Chief Justice. Bribery of legislatures was, of course, notorious; the most famous episode is recounted in Charles Francis Adams, Jr., and Henry Adams, Chapters of Erie and Other Essays (1886). An absorbing account of "influence" in all its variants, with subthemes that illuminate the importance of subnational, decentralized power, is Chester M. Destler, Roger Sherman and the Independent Oil Men (1967). For the impact of outright corruption, against a background of public policy considered in the Hurst mode, cf. William Lilley II and Lewis Gould, "The Western Irrigation Movement, 1878-1902," in The American West: A Reorientation 61-64 (Gressley ed., Univ. of Wyoming Publications, \#32, 1966). 
studies have changed the focus of investigation concerning the substantive content of 19th-century public economic policy. Not many years ago, such inquiry centered upon whether subnational government was laissez-faire or interventionist. ${ }^{23}$ Hurst's studies, deriving much of their data from the Wisconsin experience, provided an historical model of public economic policy at the state level in which "drift," incoherence, and reactive governmental responses to highly focussed private-interest demands, dispersion of governmental authority, and virtual "default" or abdication of public responsibility, all prevailed.24 By way of contrast, the Handlins argued in their study of Massachusetts public policy that the "commonwealth" ideal_- "the primordial concept of common interests," embracing a widely shared popular acceptance of active governmental intervention-prevailed there until at least 1820; there followed an erosion of social cohesion and with it of the commonwealth ideal, but still the ideal of a "humanitarian police state . . . aimed to assure equitable conditions of life and labor to all" gave coherence and focus to public policy. ${ }^{25}$ In my own study of antebellum Ohio, an arena for rapid economic development after 1820 and also the site of major efforts at state-sponsored transport enterprise, I found that there was instead a pervasive competition among policymakers who variously subscribed to the ideals of systematic planning, of localistic particularism, and of doctrinaire egalitarianism. ${ }^{26}$ As these differences of interpretation bear particularly upon the consequences of decentralized power under federalism, they are themes to which we shall return later in this paper. ${ }^{27}$

Inherent in the literature of legal-economic history, as even this summary analysis of recent scholarship suggests, are some important questions concerning the impact of federalism as a factor shaping the public sector's role and the dynamics of enterprise in U.S. economic development. But definition and pursuit

23. Cf. Herbert Heaton's comments on the "popular notion that until the fourth of March, 1933, the United States was the land of laissez faire, and the alternative notion that governments, when they have acted, have done so [in the United States] only in a regulatory capacity.", Herbert Heaton, "General Memorandum of State Studies . . 1941," reprinted in Handlin \& Handlin, supra, note 4, at 270.

24. An elaboration of Hurst's hypotheses, applied imaginatively to Congressional economic policy processes in the late 19th century, is provided by Wallace D. Farnham in "The Weakened Spring of Government: A Study in 19th-Century American History," $68 \mathrm{Am}$. Hist. Rev. 662 (1963). For a regional study, providing a brilliant overview of public policy, cf. Gene M. Gressley, West by East: The American West in the Gilded Age (Charles Redd Monographs in Western History, \#1, Provo, 1972).

25. Handlin \& Handlin, supra, note 4, at 130, 186-91, 203.

26. Scheiber, Ohio Canal Era, chs. 4, 10-11, 13.

27. Text at notes 130-134, infra. 
of these questions are seldom explicit in the literature. ${ }^{28}$ They are therefore made central to the discussion that follows here. We turn now, then, to historic American federalism and its effects (as a structural-institutional variable) in the policymaking process, in the determination of policy substance, and in the development of the private sector of the American economy.

\section{II. "FORMAL AUTHORITY" AND "REAL POWER": THEORETICAL CONSIDERATIONS}

The essential characteristic of a federal system of governmental organization is the legal or constitutional division of policy responsibilities and governmental powers between the national government and the constituent states. No refined theoretical model of a "centralized" or "decentralized" federalism is attempted here, but at least a rough theoretical structure and some key definitions will be offered. ${ }^{29}$

First of all, we must distinguish between formal authority and "real power." By formal authority, I refer to a juridical concept of legitimacy. The distribution of formal authority in a federal system is the prevailing interpretation of the Constitution. In the American case, of course, this refers mainly (though

28. The major exceptions - that is, the works that do address explicitly the problem of federal structure and its incidence-include: E.A.J. Johnson, "Federalism, Pluralism, and Public Policy," 22 J. Econ. Hist. 427 (1962), expanded in Johnson, The Foundations of American Economic Freedom: Government and Enterprise in the Age of Washington (1973); J. Willard Hurst, Legitimacy of the Business Corporation in the Law of the United States 1780-1970, 139-153 (1970); Hurst, Law and Economic Growth 53 et passim; Lawrence M. Friedman, Contract Law in America: $A$ Social and Economic Case Study 154 et passim (1965); Lawrence M. Friedman, supra, note 2; W. Brooke Graves, American Intergovernmental Relations (1964); see also note 2, supra.

29. Cf. Rufus Davis, "The 'Federal Principle' Reconsidered," 1 Austl. J. Politics \& Hist. (2 pts.), 59, 223, at 62ff., 223-26 et passim (1956), for excellent analysis of juristic theories of federalism and some analytical alternatives. William S. Livingston pleads for greater realism in the analysis of federal societies; on closer reading, "realism" is found to be synonymous with socio-cultural analysis. Livingston, "A Note on the Nature of Federalism." 67 Pol. Sci. Q. 81 (1952). Pursuing this line of discussion further, and more closely in line with recent studies such as Riker's (supra, note 2) as well is the study by C.D. Tariton, "Symmetry and Asymmetry as Elements of Federalism: A Theoretical Speculation," $27 \mathrm{~J}$. Politics 861 (1965).

Cultural differences among states and their politics, a key element in Tarlton's analysis, is made a main theme in Daniel J. Elazar, American Federalism: A View from the States (1966). This is a provocative analysis, but as will be seen many of its main historical premises differ markedly from those postulated in the present study. See id. at 2-3, 23 et passim, for Elazar's stress on "noncentralization," sharing of functions, and the alleged "concern of publics at all levels of government" with policies per se, "without regard to niceties of structure." The eminent student of federalism, in both its juridical and behavioral variants, Carl J. Friedrich, in Trends of Federalism in Theory and Practice 7-8, 9n. (1968), provides an interesting judgment on my own views and those of Elazar as set forth in earlier works. 
not exclusively) to Supreme Court prescriptions with regard to the following:

(1.) The allocation of policy responsibilities to the national government exclusively, to the constituent state governments exclusively, or to both concurrently.

(2.) The definition of constitutional limitations upon the exercise of governmental power at each level (or both levels) so far as such power may be used by government to order and regulate private citizens' or private institutions' behavior. From the obverse side, these same types of constitutional prescriptions define the rights of citizens and private institutions.

In the standard lexicon of constitutional law, these two types of prescriptive definitions by juridical arbiters refer to (a) the constitutional boundaries between national and state government, and (b) the constitutional boundaries that limit public power and define private rights.

Viewed in simplistic terms, as is too often the case in historical analysis of constitutional law, the decisions of the Supreme Court are read as an accurate "map" of how power is actually exercised and limited. The first objection to such a simplistic view is that the Supreme Court is not the sole actor in the allocation of formal authority, despite its special importance as the "final" arbiter in theory. In fact, both executive and legislative action (or abstention from action), at both the Federal and state levels, is often constrained by what officials believe to be the limits of their formal authority. ${ }^{30}$ Moreover, the state judiciaries frequently articulate counter-claims to the prevailing Supreme Court allocations of formal authority. Simplistic constitutional analysis typically treats evidence of such counterclaims as merely the "stuff" of constitutional adjudication-an element in the drama of the "great cases," but otherwise as being of little historical import. In fact, counter-claims to Supreme Court doctrines are often rather the formal expression of a pattern of governmental action-at variance with the Court's official prescriptions-that is making the federal system work quite differently from what a reading of Supreme Court decisions will suggest. Hence the paradox-one that will be encountered at several points in the historical study that follows here, in Sections III and IV-of centralized formal authority as prescribed

30. Arthur E. Sutherland, Constitutionalism in America: Origin and Evolution of its Fundamental Ideas 335 (1965); Charles M. Wiltse, The New Nation 1800-1845, 35-36, 50-51, 74, 115-23, (1961); J. Willard Hurst, "Review and the Distribution of National Powers," in Supreme Court \& Supreme Law 143-44 (Cahn ed., 1954). 
by the Supreme Court coexisting with a high degree of actual decentralization, reinforced by the juridical counter-claims of state courts and legislatures, executives, and administrative agencies.

This brings us to the second major objection that may be arrayed against interpreting Supreme Court dicta as an accurate map of centralization or decentralization: to wit, that attention to formal-authority questions alone can easily obscure the mix of "real power" in the system. The term "real power" is used here to indicate how governmental institutions actually behave-especially the range, content, intensity and effectiveness of public policies adopted in government's efforts (both state and Federal) to shape private-sector institutions and the patterns of social, political, and economic development. Ideally a mapping of power and its distribution (and effects) in the governmental system, historically considered, requires also close attention to the issues of "private government"31 and the ways in which private contractual relationships-whether they were juridically challenged or instead juridically tolerated and encouragedimpinged on both federal questions and the liberties of individual citizens. ${ }^{32}$ Although these issues of private power are recognized in several parts of the historical analysis that follows here, the main focus will be instead upon formal authority and real power in the public sector, and upon the shaping and impact of public policies in the development of the American economic order.

So far as this study is concerned with the allocation of formal authority, of course, it must keep the Supreme Court's doctrines and other officials' or agencies' constitutional claims in the forefront. But formal authority is only one element of governmental competence to act. Whether at the national or state level, governmental units were also constrained or encouraged to act by other factors such as the level of fiscal resources available; the command of personnel and expertise in magnitudes sufficient to given problems and policies; and, not least important, the congruity or incongruity of areal jurisdiction and function. These additional elements of governmental competence are particularly important in the analysis, whether historical or contemporary,

31. Cf. Arthur S. Miller, The Supreme Court and American Capitalism 140 (1968); and Grant McConnell, Private Power \& American Democracy (1966).

32. Hurst, Law and Economic Growth, at xii-xiii, 285-88, for theoretical considerations. Stewart Macaulay, Law and the Balance of Power (1970) is a penetrating study of private ordering in modern corporate marketing. 
of a federal system. ${ }^{33}$ Consider, for example, the problem of areal-functional congruity. Even if a state government enjoyed unchallenged formal authority to adopt public policy over some subject matter, and even if it also enjoyed entirely sufficient fiscal and personnel resources (organized efficiently in its bureaucracy), still truly effective action might be precluded by the fact that the state's areal jurisdiction did not extend far enough to make effective action possible. In a given field of policy, for example in the regulation of corporations, the areal jurisdiction of the states might be congruent with effective action in one period (say the 1820s and 1830s) but at a later period (say the 1890s) incongruent because of the changing scope and private power of the major, national-scale corporations. As this example suggests, the changing character of the private sector is a crucial variable in any model of centralization or decentralization: constituent states' policies that may be of decisive effectiveness in an early era may well be, in a later era, of much less importance (and hence an indicator of declining real power) when their effectiveness is perforce limited.

Another variable of crucial importance in shaping governmental policies and the distribution of real power is political will. For when the necessary elements of competence are present, translating potential power into the exercise of real power by government requires mobilization of the requisite political support. Historically, the pluralistic-coalitional nature of American political parties-throughout all the permutations of "party system" in our history ${ }^{34}$-has posed serious obstacles, for good or ill, in making government truly responsive to the electorate. ${ }^{35}$ But other obstacles were already present because of federal-style governmental structure. On the one hand, so long as federalism leaves significant (and not merely trivial) powers in the hands of the states, a strong interest group in a given state can so dominate policy decisions that it creates an enclave state-one in

33. James Fesler, "Understanding of Decentralization," $27 \mathrm{~J}$. Politics (1965); Fesler, Area and Administration (1959); York Willbern, "The States as Components in an Areal Division of Powers," in Area and Power 70-88 (Maass ed. 1959). On the concepts of governmental competence and potential power, I have found useful the discussions by Robert Dahl, "The Concept of Power," 2 Behl. Sci. 201 (1957); and Peter Bachrach and Morton S. Baratz, Power \& Poverty in Theory \& Practice, ch. 2 (1970).

34. William Riker, Democracy in the United States 115-16 (2d ed. 1965); W.N. Chambers and W.D. Burnham, The American Party Systems: Stages of Political Development (2d ed. 1975); also Nichols, supra, note 2.

35. Riker, supra, note 34; J.R. Pennock, "Responsiveness, Responsibility, and Majority Rule," 46 Am. Pol. Sci. Rev. 790 (1952); David B. Truman, "Federalism and the Party System," in Federalism (MacMahon ed.), supra, note 2, at 115-36. 
which the interests of rival political forces are decisively subordinated. $^{36}$ On the other hand, the practical limits of real power can be constrained by what have been termed "federal effects." So long as there is decentralization of significant policy responsibilities, both the promotional and the regulatory policies of the individual states will have a profound influence on similar policies in other states. Willard Hurst has provided a classic example of how federal effects have operated in our history to place practical upper limits upon a state's regulatory policies. His study of the Wisconsin lumber industry and public policy indicates that if the state legislature had opted to adopt a restrictive, conservation-minded policy governing private access to timber resources, Wisconsin's lumber firms would have suffered crippling disadvantages in the national markets, where they competed with lumber firms based in other states. ${ }^{37}$ For in those other states there were "liberal" policies, designed to reduce the business costs of lumbering. In the short run, then, Wisconsin would have faced a reduction in private income had it adopted restrictive regulations. (This might have been to Wisconsin's advantage in the long run, to be sure, but 19th century American governmental structure, policy processes, and political forces all favored the short-run calculus in policy making.) A similar dilemma is, of course, evident in controversies over environmental controls today. ${ }^{38}$ Even though the locus of power has shifted heavily to the national government in an area of regulatory policy, this type of federal effect can continue to operate. For example, it is often complained that "competition in laxity" characterizes the residual state regulations of banking today. So long as a few states persist in lax regulation of banking practices, there is significant pressure on all states to do so. ${ }^{39}$

Precisely because significant policy fields were occupied largely by the states (whether or not all of the policies pursued were consistent with Supreme Court dicta), and because state areal jurisdictions were congruent with the functions undertaken, American federalism before 1861 was decentralized. Indeed, this era may fairly be termed one of rivalistic state mercan-

36. See text at notes 205-6, infra. See also Henry Kariel, The Decline of American Pluralism 185 (1961), and McConnell, supra, note 31 at 112-18 et passim (1966).

37. Hurst, Law and Economic Growth 52-54.

38. Cf. Earl Finbar Murphy, Man and His Environment: Law (1971).

39. The term "competition in laxity" is used in a report on banking regulation in Business Week (Sept. 21, 1974), 53-54. See also William L. Cary, "Federalism and Corporate Law: Reflections Upon Delaware," 83 Yale L.J. 663 (1974). 
tilism. ${ }^{40}$ From the Civil War decade to 1910, however, there was a trend toward centralization of both formal authority and real power in the terms postulated in the foregoing rough theoretical model. Nonetheless, even as centralization occurred, many elements of decentralized power survived.

\section{DECENTRALIZATION BEFORE 1861}

\section{A. Formal Authority}

The standard constitutional histories properly emphasize the process of centralization that took place during the Marshall Court era in the realm of formal authority. Seen through the lens of constitutional jurisprudence, the dimensions of centralization were impressive. Thus we have the standard litany of Marshall Court "nationalism," beginning with' its bold assertion of the judicial-review power.41 No less important was the doctrine in McCulloch $v$. Maryland (1819) ${ }^{42}$ that the necessaryand-proper clause had given Congress power to exercise broad discretion in creating instrumentalities-in that instance, the Bank of the United States-for the effective performance of national governmental functions, even immunizing them from state taxation. "The government of the Union," Marshall declared for the Court, "though limited in its powers, is supreme within its sphere of action. ... It is the government of all, its powers are delegated by all; it represents all, and acts for all."43 The same term of the Court matched this declaration of federal supremacy with an equally expansive ruling on the contract clause in the Dartmouth College Case, ${ }^{44}$ interpreting that clause as a limitation upon the state's power to alter the terms of corporate charters. The majestic scope of national power was further expanded under the Commerce Clause interpretation set down by the Court in Gibbons $v$. Ogden (1824), ${ }^{45}$ the great

40. See Scheiber, supra, note 2, at 4-6; also the section, "What Does Federalism Mean Now?" in Michael D. Reagan, The New Federalism 156ff (1972).

41. Marbury v. Madison, 1 Cranch 137 (1803).

42. McCulloch v. Maryland, 4 Wheat. 316 (1819).

43. Id. at 404 .

44. Dartmouth College v. Woodward, 4 Wheat. 518 (1819).

45. Gibbons v. Ogden, 9 Wheat. 1 (1824). Professor Nelson has stressed the character of Gibbons, $v$. Ogden and other major commerce decisions as "instrumentalist" in the sense that they not only established the formal constitutional foundation of a national "common market" but also assured a basic practical precondition of economic growtha point also made by other scholars, though not in the context of instrumentalism as a main theme in judicial activism of the pre-1860 period. Cf. Nelson, supra, note 13, at 524-25; and also Stuart Bruchey, The Roots of American Economic Growth 97 (1965) ; Arthur
S. Miller, The Supreme Court and American Capitalism 25-28 (1968). 
steamboat case in which the Court assured at least the basic formal features of a free internal common market.

While propounding these centralizing doctrines on the matters of supremacy and the taxing power, the regulation of commerce, and the sanctity of corporate charters as contracts, the Marshall Court also dealt frontally with the problem of the constitutional and statutory reach of federal jurisdiction. These issues stemmed, in a formal sense, from Article III of the Constitution (on the judicial power); from the 1789 Judiciary Act;46 and from the Eleventh Amendment (1798), which provided a measure of sovereign immunity for the states against suits in the national courts. ${ }^{47}$ The jurisdictional issue had aroused deep controversy both during the Ratification debates of 1787-88 and during Congress's consideration of the 1789 Judiciary Act. ${ }^{48}$ But the basic juridical theory of federalism was not alone at stake. So were partisan objectives, pitting the Federalists against the opponents of centralization who formed the core of the Jeffersonian Republican party. So, too, were important economic interests; they included the giant speculative land companies that sought federal protection from state actions adversely affecting them, the rising commercial elements that needed maximum uniformity of law to conduct multistate transactions on a secure legal basis, and (at least prospectively, if not immediately) large-scale investors and banking firms whose business horizons stretched out across state lines. ${ }^{49}$ Emblematic of the mixed motivations

But it is important to keep in the forefront of analysis that major doctrinal issues bearing on fundamental distribution of formal authority were also before the court in Gibbons. On the one hand, as Professor Mann has shown, the Marshall Court was confronted with the basic question of whether or not property rights, immunities, and limitations derived from the states, together with the related question of "nationalization" of private rights. And, on the other, the Court confronted the classic Federalist-Jeffersonian (or, better, Federalist-Antifederalist, 1787-style) doctrinal differences as to the character of national supremacy and state sovereignty. Cf. W. Howard Mann, "The Marshall Court: Nationalization of Private Rights and Personal Liberty from the Authority of the Commerce Clause," 38 Ind. L.J. 117, 180-81, 212, 225-26 et passim (1963).

Although Mann correctly emphasizes the dogmatic strictures of the Chief Justice in his opinion for the Court (id. at 232-33), also casting new light on the nationalism of Justice Johnson ( $i d$. at 23437 , he fails to recognize the degree to which the states actually continued to exercise essential controlling powers over the conditions of interstate commerce during the ensuing decades. Cf. Harry N, Scheiber, "The Rate-Making Power of the State in the Canal Era," 77 Pol. Sci. Q. 397 (1962); and the text, infra, at notes 134-35.

46. 1 U.S. Stats. 73 (Sept. 24, 1789). See the classic study by Charles Warren, "New Light on the History of the Federal Judiciary Act of 1789," 37 Harv. L. Rev. 49 (1923).

47. Cf. Clyde E. Jacobs, The Eleventh Amendment and Sovereign Immunity chs. 1-3 (1972).

48. Warren, supra, note 46; John P. Frank, "The Historical Bases of the Federal Judicial System," 12 L. \& Contemp. Probs. 3 (1948).

49. Kathryn Turner, "Federalist Policy and the Judiciary Act of 1801," 
and concerns of those leaders who sought to expand federal jurisdiction-to the horror of Jeffersonian jurists and politicians who counted on state sovereignty for their own power base, or who adhered to states' rights on principle-was the private avowal of one Federalist spokesman who helped engineer passage of the short-lived Judiciary Act of 1801: He wrote that it was necessary "to spread out the judicial so as to render the justice of the nation acceptable to the people, to aid the national economy, and to overawe the licentious, and to punish the guilty." 50

The peculiar Federalist Party version of "licentious" and "guilty" behavior, qua political crimes, surfaced in stark and nasty form in the Alien and Sedition Act prosecutions-lending further volatility to the "question of federal" jurisdiction. 51 Champions of states' rights were sensitized even further to the issue of Supreme Court aggrandizement of power by the decision in Chisholm $v$. Georgia, by the debate over the Eleventh Amendment, and by the 1801 Judiciary Act controversy. ${ }^{52}$ Meanwhile, basic questions of states' powers to abridge vested property rights were coming to the forefront in a series of important cases then working their way through the lower federal courts. ${ }^{53}$

It was against this stormy political background that the Marshall Court vigorously upheld the supremacy clause in review of state decisions on federal questions, turned back challenges to the constitutionality of Section 25 of the 1789 Judiciary Act, and reaffirmed its own prerogatives in establishing the interpretation of diversity standing-at the same time hedging

22 Wm. \& Mary Q. (3d. ser.) 3, 23-31 (1965). Among the leading federal cases involving land titles and "federal questions" already in progress in the lower courts by 1801 were those that culminated in Fletcher $v$. Peck, 6 Cranch 87 (1810), on the Yazoo land claims in Georgia; and in Martin v. Hunter's Lessee, 1 Wheat. 304 (1816), on major land claims in Virginia. On the range of early cases, many bearing on significant propertied interests, that sharpened the debate over the proper scope of federal judicial review, cf. Charles $G$. Haines, The American Doctrine of Judicial Supremacy ch. 8 (2d ed. 1959). For analysis of federal cases by source of jurisdiction and type of substantive issue, to 1815 , see Frank, supra, note 48, at 1622. See also Dwight F. Henderson, Courts For $A$ New Nation (1971).

50. Theodore Sedgwick to Rufus King, Nov. 15, 1799, quoted in Turner, supra, n.49, at 9. Cf. Richard E. Ellis, The Jeffersonian Crisis: Courts and Politics in the Young Republic (1971), a rich and incisive analysis of the judiciary as an issue in the new nation's politics.

51. Cf. James Morton Smith, Freedom's Fetters: The Alien and Sedition Laws and American Civil Liberties (1956).

52. Chisholm v. Georgia, 2 Dall. 419 (1793), in which the Supreme Court held that its jurisdiction embraced suits against a state by citizens of other states, and the reaction to the decision (culminating in adoption of the 11th Amendment), may be traced in Jacobs, supra, note 47, at 46-57 et seq. Cf. Doyle Mathis, "Chisholm v. Georgia: Background and Settlement," 54 J. Am. Hist. 19 (1967).

53. See note 49 , supra. 
severely the reach of the Eleventh Amendment. ${ }^{54}$ The wide scope of diversity jurisdiction that the Court established in these decisions also laid the groundwork for its highly controversial interventions in cases where state legislatures and courts had responded too favorably to demands for relief laws or for actions to defend tenant and squatter interests from the claims of speculators. In this respect, diversity doctrine reinforced the other doctrinal supports erected by the Marshall Court in defense of vested property rights. ${ }^{55}$

Other "centralizing" decisions touched additional areas of economic policy of major importance to the states. In Bank of of the U.S. $v$. Deveaux (1809) ${ }^{56}$ the Court asserted its power to define diversity of citizenship as it applied to corporations, albeit doing so in terms that made it fairly difficult for corporate litigants to obtain transfer of cases to the federal forum. ${ }^{57}$ Perhaps no element of the states' legislation jeopardized vested property and contractual rights more menacingly than the bankruptcy and relief laws. Such laws abounded in the states and were astounding in their variety. Their constitutionality was reviewed by the court in 1819 , when the justices struck down a law that covered debts contracted before its enactment; not until 1827 did the Court clarify its view, approving prospective bankruptcy laws affecting a state's own citizens. ${ }^{58}$ At a time

54. U.S. v. Peters, 5 Cranch 115 (1809); Martin v. Hunter's Lessee, 1 Wheat. 304 (1816); Cohens v. Virginia, 6 Wheat. 264 (1821). The challenge to $\S 25$ of the 1789 Judiciary Act, which Virginia had sought to have declared unconstitutional in Cohens $v$. Virginia and which pertained to federal review of state decisions in federal questions, is analyzed in Jacobs, supra, note 47, at 81-87. These and related decisions are also considered ably, in the context of the formal juridical theory of sovereignty and federalism, in Robert K. Faulkner, The Jurisprudence of John Marshall ch. 2 (1968).

55. Paul W. Gates, "Tenants of the Log Cabin," 49 Miss. Valley Hist. Rev. 3 (1962) treats in detail the legal-economic and political history of the famous controversy over land titles and occupiers' claims, culminating in Green $v$. Biddle, 8 Wheat. 1 (1823). For a different view, of. Gerald T. Dunne, Justice Joseph Story and the Rise of the Supreme Court 208-13, 219-29 (1970). Failure of sister states to rush to the support of Kentucky, Virginia, and other litigants in this and related cases gave rise to serious concern that "the just pride, the sovereignty, and constitutional independence" of the states had been dangerously vitiated. Sen. Talbot of Kentucky, in Congressional debate, quoted in Erwin Surrency, "A History of Federal Courts," 28 Mo.'L. Rev. 214, 229 (1963). See also Mary Tachau, "The Federal Courts in Kentucky, 1789-1816," (Ph. D. dissertation, U. of Ky., 1973).

56. Bank of the U.S. v. Deveaux, 5 Cranch 61 (1809). Cf. Gerald Henderson, The Position of Foreign Corporations in American Constitutional Law (1918).

57. See note 47 , infra.

58. Sturges v. Crowninshield, 4 Wheat. 122 (1819), which ruled a New York bankruptcy law unconstitutional but in ambiguous terms (apparently on grounds of its retroactivity). Cf. McMillan v. McNeil, 4 Wheat. 209 , a case immediately following, also ambiguous and pertaining to application of English bankruptcy law to a contract made 
when several states were experimenting with partially or wholly state-owned banking institutions, particular significance rested in the Marshall Court's decision of $1824^{59}$ that such state instrumentalities might be sued to enforce federal constitutional rights. On the other hand, state power over federal instrumentalities was curbed in absolutist terms in Weston $v$. Charleston (1829), ${ }^{60}$ a decision immunizing United States bonds and notes from state taxation.

The degree to which the Taney Court attenuated the essential nationalism of major Marshall Court doctrines is a matter of considerable scholarly dispute. But even historians who stress elements of Taney Court jurisprudence that tended toward decentralization of formal authority commonly recognize that there was little diminution of the Court's assertion of centralized judicial power, in its own hands. ${ }^{61}$ Moreover, the Court in the Taney era unquestionably expanded the central government's authority in the field of maritime law, substituting a far more generous interpretation of admiralty jurisdiction for the Marshall Court's surprisingly modest adoption of English rules. ${ }^{62}$ It also buttressed the power of Congress to provide for federal law enforcement without interference by the states in the leading case of Ableman $v$. Booth ${ }^{63}$ Diversity citizenship for corporations also received an expansive new interpretation by the Court in 1844: By defining the corporation as having citizenship in the state where it was chartered, the decision of Railroad $v$.

in this country. In Ogden v. Saunders, 12 Wheat. 213 (1827), the Court finally clarified its position and (over Marshall's dissent) held prospective bankruptcy laws to be constitutional. The ambiguities of constitutional doctrine probably stayed the hand of several states then considering such legislation. See Peter J. Coleman, Debtors and Creditors in America: Insolvency, Imprisonment for Debt, and Bankruptcy 1607-1900 32-34 (1974); Ernest S. Bates, The Story of the Supreme Court 118-19 (1936); R.L. Hale, "The Supreme Court \& The Contract Clause," 57 Harv. L. Rev. 512, 519 (1944). On the depression crisis and legislative responses, cf. Samuel Rezneck, "The Depression of 1819-1822," 39 Am. Hist. Rev. 28 (1933).

59. Bank of the U.S. v. Planters' Bank, 9 Wheat. 904 (1824); cf. Bank of Kentucky v. Wister, 2 Pet. 318 (1829).

60. Weston v. Charleston, 2 Pet. 449 (1829).

61. See Robert J. Harris, "Chief Justice Taney: Prophet of Reform and Reaction," American Constitutional Law: Historical Essays 93, 98ff. (Levy ed. 1966); Alpheus T. Mason, The States' Rights Debate 192 (2d ed. 1972); Carl Brent Swisher, The Taney Period, 1836-1864, 358 et passim (Oliver Wendell Holmes Devise History of the U.S.' Supreme Court, V, 1974).

62. Propeller Genesee Chief v. Fitzhugh, 12 How. 443 (1851). Taney's opinion for the Court stressed not nationalist doctrine, however, but commercial and geographic imperatives on the one hand, and, on the other, a variant of states' rights (viz., the need of interior states on lake and river waters to enjoy "perfect equality in rights and privileges" with seaboard states). Id. at 454 .

63. Ableman v. Booth, 21 How. 506 (1859). Cf. Swisher, supra, note 61, at 653-75. 
Letson ${ }^{64}$ "opened the federal courts to corporate refugees from hostile state courts" in unprecedented numbers. ${ }^{65}$

"There is," as Professor Hurst has written, "at least as much concern for the federal balance as there is concern for the corporation in the policy brew of Bank of Augusta v. Earle,"6e another Taney Court decision of signal importance to the emergent economic order in Jacksonian America. ${ }^{67}$ The Court ruled that, under the principle of comity, there was a presumption that foreign (out-of-state) corporations could do business in a state unless the latter adopted a clear and explicit policy of exclusion. Yet the decision also affirmed that states enjoyed the power to exclude or place limitations upon foreign corporations-as many of them did, for example, in limiting the power of foreign railroad corporations to acquire in-state franchises. The decentralizing potential of the ruling, despite the adoption of comity principles, was underlined by the Court's corollary dictum that a corporation-though a "person" for purposes of standing and litigation-did not enjoy the privileges and immunities guaranteed in Article IV of the Constitution. ${ }^{68}$

If ambiguities thus shrouded somewhat the import of Bank of Augusta, "mirror[ing] the tensions of mid-19th-century public policy toward the legitimacy of the corporation,"69 similar uncertainties inhered in the ostensibly nationalistic, centralizing decision of Swift $v$. Tyson (1842). ${ }^{70}$ Speaking through Justice Story, the Court in Swift $v$. Tyson asserted the primacy of general rules of the "Law Merchant" over state rules in commercial cases, when these cases were brought in federal court on

64. Louisville, etc. R.R. v. Letson, 2 How. 497 (1844). The ruling in Letson was elaborated in Marshall v. Baltimore \& Ohio R.R., 16 How. 314 (U.S. 1854) which established a "conclusive presumption" that all the shareholders of any corporation were citizens of the state that chartered that corporation; cf. Taney's further comments in Ohio \& Miss. R.R. v. Wheeler, 1 Black. 286, 296 (1862). This ruling superseded the older one, in Strawbridge v. Curtiss, 3 Cranch 267 (1806) that had required "complete diversity." For a full discussion, see Dudley O. McGovney, "A Supreme Court Fiction: Corporations in the Diverse Citizenship Jurisdiction of the Federal Courts (Pt. 1)," 56 Harv. L. Rev. 853 (1943).

65. Harris, supra, note 61 , at 102.

66. Bank of Augusta v. Earle, 13 Pet. 519 (1839).

67. Hurst, Legitimacy of the Business Corporation, supra, note 28, at 65.

68. Id. at 64-65. The immediate response of Alabama to the decision was to adopt a new statute specifically declaring it unlawful for any foreign corporation to engage in banking and discount operations within the state. The long-term influence of the decision rested in Taney's dicta on (1) privileges and immunities, (2) the "geographic theory" of the corporation as existing juridically in its state of charter, and (3) the power of a state "to repudiate the principle of comity." G.C. Henderson, The Position of Foreign Corporations in American Constitutional Law 47-49 (1918).

69. Hurst, Legitimacy of the Business Corporation, supra, note 28, at 64 .

70. Swift v. Tyson, 16 Pet. 1 (1842). 
grounds of diversity of citizenship. Recent commentators have stressed that the decision, though obviously centralizing in its assertion of a national common law, did not derive from a nationalistic theory of federalism so much as it did from a concern to prove stability of rules in multistate commercial transactions and from a faith in the common law as a source of vital liberties. ${ }^{71}$ However this may be, the decision placed national power in direct confrontation with the state judiciaries in a vital area of public policy. ${ }^{72}$ Moreover, the concept underlying Swift-that certain elements of commercial law required national uniformity-carried over into other areas in subsequent Taney Court decisions (some of them centralizing in effect, others affirming state authority and legitimating divergences in policy among states)..$^{73}$

There is no gainsaying the range and potential impact of formal centralizing doctrines, not only the Marshall Court's but the Taney Court's as well, that have been reviewed here. Nonetheless, an impressive degree of decentralized formal authority remained. Indeed, the Marshall Court itself had qualified some of its landmark centralizing decisions. Even in so uncompromisingly nationalistic a decision as Cohens $v$. Virginia, Marshall himself provided at least a rhetorical legacy that could be mobilized to rationalize the "dual federalism" ${ }^{4}$ concept championed by the Taney Court; thus Marshall declared that "these States . . . are members of one great empire-for some purposes sovereign,

71. Note, "Swift v. Tyson Exhumed," 79 Yale L.J. 284 (1969); Charles A. Heckman, "The Relationship of Swift $v$. Tyson to the Status of Commercial Law in the 19th Century and the Federal System," 17 $A m$. J. Leg. Hist. 246 (1973). See also Waterman, "The Nationalism of Swift v. Tyson," 11 N. Car. L. Rev. 125 (1936).

72. Moreover, the conflict continued after 1842 , on which see text at notes 110-15, infra. For a view of the Swift doctrine as both nationalizing and extremely mischievious in its consequences, see Warren, New Light, supra n.46, at 84ff.; and Felix Frankfurter, "Distribution of Judicial Power between United States and State Courts," 13 Cornell L.Q. 499, 526 (1928). Contra, H.E. Yntema \& G. Jaffin, "Preliminary Analysis of Concurrent Jurisdiction," $79 \mathrm{U}$. of $P a$. L. R. 869, 881-88 (1931).

73. Cf. Lane v. Vick, 44 U.S. 464 (1845), regarding wills, Williamson v. Berry, 49 U.S. 495 (1850), regarding private actions; dictum in Murray v. Gibson, 56 U.S. 420, 425 (1853); and Watson v. Tarpley, 59 U.S. 517,521 (1855), that a statute that violates general commercial law is "inadmissable." These and other cases are considered in Note, "Swift $v$. Tyson Exhumed," supra note 71 , at $285 \mathrm{n} ., 296 \mathrm{n}$. See also Rowan v. Runnels, 5 How. 133, 139 (1847).

74. Cf. Mason, supra, note 61 , at 191 defining "dual federalism" as the doctrine of "two mutually exclusive, reciprocally limited fields of power-that of the national government and that of the states. The two authorities confront each other as equals across a precise constitutional line, defining their respective jurisdictions." "Marshall, of course, did not see federal and state governments as "equals." But once that logical step (admittedly a long one) had been made, the bridge from concurrent power to dual federalism had its logical structure ready. 
and for some purposes subordinate."75 And in Gibbons $v$. Ogden, asserting national power over commerce, Marshall acknowledged that inspection, quarantine, and other laws enacted under the states' police power formed "a portion of that immense mass of legislation which embraces everything within the territory of a state, not surrendered to the general government; all of which can be most advantageously exercised by the states themselves."76 And five years later, in Willson v. Blackbird Creek Marsh Company, ${ }^{77}$ the Chief Justice formulated the concept of the "dormant commerce power" to validate a state's legislation affecting a feature of interstate commerce on which Congress had taken no action. Also, refraining from positive assertion of a federal common law (even though implicitly reserving the Supreme Court's power to invalidate state rules), the Marshall Court upheld what it perceived to be established state rules concerning wills, real property, and statutes of limitations and of frauds. ${ }^{78}$ In 1825, moreover, the Court affirmed in broad terms its policy of adopting the construction given a state's own statute laws by the courts of that state. ${ }^{79}$ Two years later, the Court declared it "a principle . . . obviously just, and . . . indispensably necessary, under our system of government," that settled rules of real property in the states must be honored by the federal courts.80 These judicial acts of deference toward state legislation and established rules of decision-together with the doctrine that the first eight Amendments were limiting only upon Congress and not upon state action ${ }^{81}$-reinforced the juridical basis for the very substantial variety that prevailed among the states in matters that impinged vitally on private-sector

75. Cohens v. Virginia, 6 Wheat. 264 (1821).

76. Gibbons v. Ogden, 9 Wheat. 1,203 (1824). For a recently published analysis stressing that the decision in Gibbons $v$. Ogden came against a background of intense pressure on the Supreme Court to extend the legitimacy of the states' formal authority in other areas of lawpressure that the Court, at its peril, largely resisted forthrightlysee David B. Roe and Russell K. Osgood, "United States Supreme Court, February Term 1824," 84 Yale L.J. 770, esp. at 806-7 (1975).

77. Willson v. Blackbird Creek Marsh Company, 2 Pet. 245, 252 (1829).

78. The following cases are discussed in Note, "Swift v. Tyson Exhumed," supra, note 71, at 291-93: Robinson v. Campbell, 16 U.S. 212 (1818), in which the Court indicated that under certain circumstances state rules could not be validated in federal litigation; Preston's Heirs v. Bowmar, 19 U.S. 580 (1821), accepting a state rule as "not unreasonable, or founded in clear mistake," and Daly v. James, 21 U.S. 495, 535 (1823), in which the Court declared itself merely "disposed to acquiesce" in a Pennsylvania rule.

79. Elmendorf v. Taylor, 10 Wheat. 152, 159 (1825). Cf. Barker v. Jackson, 2 F. Cas. 811 (No. 989) (C.C.D.N.Y. 1826), expanding this doctrine to cover cases of dispute as to alleged conflict between laws of a state and the constitution of the state in question.

80. Jackson v. Chew, 12 Wheat. 153 (1827).

81. Barron v. Baltimore, 7 Pet. 243 (1833). 
economic activity and organization. ${ }^{82}$

In perhaps the most notable modification of Marshall Court doctrine, the Taney Court's Charles River Bridge decision in 1837 ruled that charter privileges and immunities should be construed narrowly, in order to expedite technological innovation and to admit changes of state policy that were necessary to sustain robust competition in the economy. ${ }^{83}$ Taney's opinion in this case, as Professor Hurst has written, was "the classic statement of policy in favor of freedom for creative change as against unyielding protection for existing commitments." 84 Recently, Professor Kutler has made a strong argument against reading the Taney Court's Charles River Bridge and related decisions in the abstract perspective of state's rights; Kutler points out that if such decisions "admittedly enhanced the powers of the states," it was not "necessarily at any appreciable expense to the national government." of the Webster-Story view, which would have set up the federal contract clause and the Dartmouth College doctrine as barriers to the sort of action that Massachusetts' legislature had taken in confronting the Charles River Bridge proprietors with competition from a new bridge over the Charles. Thus, on grounds of the state's need to exercise sovereign police powers, Taney flatly stated the case against implying corporate powers or immunities from charters:

We cannot deal thus with the rights reserved to the States; and by legal intendments and mere technical reasoning, take

82. How the Supreme Court became embroiled in the sort of intense controversy that could easily derive from deference to the state courts in matters of interpreting their own constitutions became evident in the 1860's, when vast differences (and one major state-court reversal) surfaced on the matter of bond repudiation. See Scheiber, "The Road to Munn," supra, note 13, at 393-94, on Leffingwell v. Warren, 2 Black. 599 (1862); and Gelpcke v. Dubuque, 1 Wall. 175 (1864).

Earlier, a thorny judicial confrontation on similar lines had involved the Court in determining the status of debts incurred to purchase slaves on credit in Mississippi from 1833 to 1837 . During that time the state's constitution had barred commercial importation and sale of slaves; In the absence of legislation on the subject, and (as the Court found) lacking a definitive ruling to the contrary by the state judiciary, the Court ruled that debts incurred for such sales would be binding. This ruling affected those transactions affected by citizenship diversity. Groves v. Slaughter, 15 Pet. 449 (1841). The State court, in Brien v. Williamson, 8 Miss. 14 (1843), ruled to the contrary, its decision affecting transactions between the state's own residents. In Rowan v. Runnels, 5 How. 134 (1847), however, the Supreme Court reaffirmed its Groves decision. Cf. Hale, supra, note 58, at 854-62; William Goodell, The American Slave Code in Theory and Practice, 48-49n (1853).

83. Charles River Bridge v. Warren Bridge, 11 Pet. 420 (1837).

84. Hurst, Law and the Conditions of Freedom 27.

85. Stanley I. Kutler, Privilege and Creative Destruction: The Charles River Bridge Case 131 (1971). Cf. Gerald Garvey, "The Constitutional Revolution of 1837 and the Myth of Marshall's Monolith," 18 W. Polit. Q. 27 (1965). 
away from them any portion of that power over their own internal police and improvement, which is so necessary to their well being and prosperity. 86

The Taney Court further narrowed potential contract-clause limitations on the state's powers in the West River Bridge Case $(1848)^{87}$ - a decision of the same order of importance as that of Charles River Bridge. Directly at issue in West River was the right of the states to engage in takings under their eminent domain powers. As in Charles River Bridge, the issue arose from a state legislature's efforts to expedite the building of transport improvements. In West River, the State of Vermont seized the entire property (including the franchise itself) of a chartered bridge company, to make the corporation's bridge part of a new public highway route. ${ }^{88}$ The corporation sued to enjoin the taking, invoking the Dartmouth College doctrine. A franchise, it was argued by the company's attorney, Daniel Webster, could not be taken in the same way as physical property. Warning that if the Supreme Court upheld Vermont's action, "our State Governments would be but unlimited depotisms over the private citizens," Webster hinted darkly at not only the dangers of "the most levelling ultraisms of Antirentism or Agrarianism" but also the prospect of "Abolitionism [being] ... successfully advanced." 89 But 1848, when railroad projects, state roadbuilding, and bridge enterprises were flourishing amidst economic expansion, was not 1787 or 1819 , when a rash of stay, relief, and bankruptcy laws had awakened dark fears of property rights being capriciously extinguished amidst commercial crisis or general economic depression. Moreover, 1848 was a time when concern about corporate monopoly, as an intractable obstacle to material progress, was abroad in the land.90 And so, despite Webster's entreaties, the Taney Court came down again in favor of strong state powers and a model of federal government structure that left powerful instruments of economic control in the

86. Charles River Bridge v. Warren Bridge, 11 Pet. 420 at 552 (1837).

87. West River Birdge v. Dix, 6 How. 507 (1848).

88. Id. The case combined two appeals, one from the Vermont supreme court and one from a state circuit court.

89. Id. at 520-21. Leonard Levy erroneously accepts at face value the extraordinary claim by Webster that the eminent domain power had only lately been admitted in American law and was derived in any event from the laws of despotic governments. Levy, supra, note 21 at 120n. On earlier explicit mention of "eminent domain" and the invalidity of Webster's spurious argument, cf. Scheiber, "Road to Munn," supra, note 13, at 379n. Justice Daniel disposed readily of Webster's claim. 6 How. 507 at 533-34.

90. Thus the Boston Post, Feb. 4, 1848, welcomed the West River Bridge decision as a blow against "the power of monopolies . . . in favor of popular rights." Quoted in Charles Warren, The Supreme Court in United States History, II, 164 (1947 ed.). 
hands of the constituent States: The case involved, as the Court declared,

the interior polity and relations of social life, which should be regulated with reference to the advantages of the whole society. This power, denominated the eminent domain of the State, is, as its name imports, paramount to all private rights vested under the government, and these last are, by necessary implication, held in subordination to this power; and must yield in every instance to its proper exercise. ${ }^{21}$

As to adequacy and justice of the compensation awarded, moreover, the Court declared that this was a matter for the State's agencies themselves to decide. ${ }^{\theta 2}$ The sweeping character of the discretion thus conceded became clear two years later, in Mills $v$. St. Clair County (1850), ${ }^{93}$ in which the Taney Court refused to interpose its power when the State of Illinois took the land and franchise rights of a ferry owner and transferred them to another ferry operator. Admitting the blatant inadequacy of the compensation given the property owner in this taking, still the Court kept hands off. To do otherwise, Justice Catron declared for the Court in upholding the Illinois Supreme Court's decision, would result in making "all State laws . . . under whose sanction roads, ferries, and bridges are established ... subject to our supervision." Where obvious injustice had occurred in an eminent domain proceeding, the Court concluded, the citizens of the state must seek redress from their own legislature and courts.

In ruling that federal judicial power could not properly be invoked to challenge this "attribute in the States"93 - their sovereign right to exercise the police power and eminent domain power-the Court erected a pillar of decentralizing federalism to stand alongside another, in the field of the commerce power. In the commerce field, the Court moved (though sometimes rather shakily) toward a definition of "concurrent powers" and an expanded definition of state police powers that further supported the juridical concept of inalienable sovereign "attribute[s] in the States." Thus in New York $v$. Miln (1837), ${ }^{96}$ decided the same year as Charles River Bridge, the Court's majority asserted the "complete, unqualified, and exclusive" character of the police powers (such as quarantine laws, at issue in this case), even when they affected commerce. The Miln decision, as Kutler has written, not only asserted the validity of state laws touching com-

91. West River Bridge v. Dix, 6 How. 507 at 532 (Daniel, J.).

92. Id. at $\mathbf{5 3 5 .}$

93. Mills v. St. Clair County, 8 How. 569 (1850).

94. Id. at 584 .

95. West River Bridge v. Dix, 6 How. 507 at 532 (1848).

96. New York v. Miln, 11 Pet. 102 (1837). 
merce in the absence of Congressional action, but also "seemed to take a step" toward the doctrine that state police authority might be held superior to the federal commerce power. ${ }^{87}$ Subsequent cases invoking the commerce clause failed to produce a solid majority of the Court in favor of any predominant doctrine. But in each of them, there was significant sentiment in favor of certain reserved or prior state powers "as exclusive in nature and hence as capable of setting an independent limitation to the delegated powers of the United States."98 Moreover, in 1852 the Court held that despite Gibbons $v$. Ogden a state might establish a navigational monopoly of purely intrastate character. ${ }^{98}$ A decade later, it declared that a state might regulate a ferry that was obviously local in nature, even if it plied an interstate waterway, indeed a river boundary between two states. ${ }^{100}$ Similarly, the Court upheld state regulations of coastal fisheries against commerce clause claims. ${ }^{101}$

As the history of the Supreme Court's adjudication of commerce power questions makes clear, a structure of formal authority in which significant powers were left with the constituent state governments took shape in part because of federal abstention. That is to say, there were many vital areas of law and public policy in which Congress simply took no positive

97. Kutler, supra, note 85, at 124. Edward S. Corwin, commenting upon the Miln doctrine of inalienable police powers, states that the opinion stood the Tenth Amendment on its head by defining state power "prior to the definition of national power, and not vice versa;" it threatened to "render the supremacy clause entirely nugatory." Edward S. Corwin, The Commerce Power Versus State Rights 126 (1936).

98. Corwin, supra, note 97, at 170 . For a summary of the relevant cases, viewed from a perspective stressing the more nationalistic strain in the decisions of the 1840 s and 1852 , see Benjamin F. Wright, The Growth of American Constitutional Law 68-71 (1967 ed.). Compare Felix M. Frankfurter, The Commerce Clause Under Marshall, Taney, and Waite, Ch. 2 (1937).

In a highly suggestive critical overview of the Taney Court, Professor Newmyer has argued recently that "doctrinal confusion and irresolution" marked Commerce Clause adjudication: "For fourteen years, from Miln to Cooley [53 U.S. 299 (1852)], the Justices squabbled inconclusively over questions of concurrent power, federal exclusivism, and state police power. The principle of 'selective exclusiveness' set forth in the Cooley decision was less a doctrinal clarification than it was an agreement to stop looking for one." Newmyer, "History over Law: The Taney Court," 27 Stan. L. Rev. 1373, 1378 (1975). For useful analysis of the Commerce Clause, as well as eminent domain, Contract Clause, and other important cases of the Marshall and Taney eras, see also Maurice G. Baxter, Daniel Webster \& The Supreme Court (1966).

99. Veazie v. Moor, 14 How. 567 (1852).

100. Conway v. Taylor's Executor, 1 Black 603 (1862).

101. Smith v. Maryland, 18 How. 71 (1855). For a detailed discussion of concurrent powers doctrines, and their decentralizing effects on the structure of formal authority, see the classic article by J.A.C. Grant, "The Nature and Scope of Concurrent Powers," 34 Colum. L. Rev. 995 (1934). 
action, and the Supreme Court advanced no exclusive claims for a "dormant" congressional power. The issue of national versus state jurisdiction therefore was not precipitated. Hence the states enjoyed virtually exclusive control over elections, civil rights, education, family and social relations, and criminal law. Of signal importance for analysis of federalism as a factor in legal-economic history, the states also enjoyed wide-ranging formal authority to regulate labor relations, including slavery. ${ }^{102}$ The states were also the arena in which public policy regarding corporations principally developed; indeed, until the transcontinental railroads were chartered in the early $1860 \mathrm{~s}$, the charters of the First and Second Banks of the United States constituted the entire corpus of federal statutory corporation law. In the field of banking law, both Congressional and state powers were vigorously exercised, as the states' range of formal authority remained large. Moreover, as we have seen, the states enjoyed virtually unchecked authority to expropriate private property under laws of eminent domain ${ }^{103}$-a field of power that was of central importance in the development of state transport programs. Eminent domain also had become increasingly important by mid-century as a potent instrument for allocation of resources by the states to encourage manufacturing and other forms of enterprise. ${ }^{104}$

Even when the Supreme Court asserted "nationalistic doctrines to establish limits upon the antebellum states' formal authority, the state judiciaries often initiated significant counterthrusts. A few prominent examples will suffice to illustrate this element of dynamic pre-1861 federalism. Best known is the successful resistance by the states (with aid and comfort, to be sure, of the federal Executive) to the Marshall Courts' doctrine of 1832 in Worcester $v$. Georgia ${ }^{105}$ that state laws could have no force in the Indian territories. In Georgia itself, as in Alabama, Wisconsin, and Tennessee, the state courts blatantly defied the Supreme Court's ruling, ${ }^{106}$ occasionally with the sup-

102. Of course, the law of fugitive slaves and the law and administration of their rendition-culminating in the Dred Scott decision-was inescapably one that confronted Congress and demanded federal policy. For a remarkable, and insightful, analysis of how the mere act of confronting slavery in the territories escalated constitutional issues and intensified the response to fugitive-slavery questions, see Arthur Bestor, "The American Civil War as a Constitutional Crisis," $49 \mathrm{Am}$. Hist. Rev. 329 (1964) and "State Sovereignty and Slavery," $54 \mathrm{~J}$. IIl. St. Hist. Soc'y. 1 (1961).

103. Text at notes 87-94, supra.

104. Cf. Scheiber, supra, note 14, at $232 \mathrm{ff}$.

105. Worcester v. Georgia, 31 U.S. 515 (1832), esp. at 561.

106. State v. Tassels, Dudley 229 (Ga. 1830); Caldwell v. State, 1 Stew. \& Port. 327 (Ala. 1832); State v. Foreman, 16 Tenn. 256 (1835); State 
port of lower federal courts. ${ }^{107}$ Also well known was Ohio's continuing resistance for several years to the Marshall Court's decision in McCulloch $v$. Maryland, banning state taxation of the national bank. ${ }^{108}$ Even as late as the 1850 s, moreover, the Ohio supreme court engaged in a continuing confrontation with the federal courts over whether a tax exemption written into a bank charter was inviolable (under the Dartmouth College doctrine) or, as the state court held, revocable on grounds that the state taxing power was an essential and inalienable attribute of sovereignty. ${ }^{109}$ Indeed, the continuing litigation of cases under the commerce clause-cases involving the validity of state quarantine, licensing, and similar regulatory statutes-was emblematic of the persistence with which the states asserted their claims to legitimate authority impinging upon freedom of interstate commerce.

Equally persistent (and effective) pressure against nationalizing doctrine was evident in the state judiciaries' reaction to Swft $v$. Tyson, ${ }^{110}$ the 1842 Supreme Court decision written by Story declaring the existence of a federal common law under the doctrine of a "general jurisprudence" in the field of commercial transactions. There followed a parade of state decisions sturdily reasserting the autonomy of the states in defining commercial-law rules. Exemplary of them was Stalker v. McDonald (1843), ${ }^{111}$ in which the New York high court flatly rejected the Supreme Court's effort to achieve uniformity. "In questions of local law," the Chancellor wrote for the court, "and in the constitution and statutes of the state, the decisions of the highest court of judicature of the state are the evidence of what the law of the state is; and are to be followed in preference to those of any state or country, or even of the United States."112 Mississippi quickly followed, its chief justice writing for the court that "state tribunals may justly claim to decide for themselves all questions of state policy, and questions involving the inter-

v. Doxtater, 47 Wisc. 278 (1879). Cases cited in this and following note are considered in Grant, supra, note 101, at 1000.

107. U.S. v. Bailey, 24 F. Cas. 937 (No. 14, 495) (C.C.D. Tenn. 1834); U.S. v. Cisna, 25 F. Cas. 422 (No. 14,795) (C.C.D. Ohio 1835); U.S. v. Ward, 28 F. Cas. 397 (No. 16,639) (C.C.D. Kans. 1863).

108. Supra, note 42. Also, Osborn v. Bank of the U.S., 9 Wheat. 738 (1824).

109. Bank of Toledo v. Bond, 1 Ohio St. 622 (1853); Dodge v. Woolsey, 59 U.S. 331 (1855); Sandusky City Bank v. Wilbor, 7 Ohio St. 481 (1857); Skelly v. Jefferson Branch Bank, 9 Ohio St. 607 (1859), rev'd 1 Black 436 (1862).

110. Swift v. Tyson, 16 Pet. 1 (U.S. 1842).

111. Stalker v. McDonald, 6 Hill. 93 (N.Y. 1843).

112. Id. at 95. 
pretation of state constitutions." ${ }^{113}$ So did others. ${ }^{114}$ But even more startling is the evidence that more than a decade later, the state courts were continuing stoutly to resist uniformity of commercial law-and the commercial transactions of the nation were going forward largely according to the rules generated independently (and at variance with one another) by the individual states. Thus the Minnesota court in 1856 was applying the New York doctrine regarding negotiable instruments, rather than Story's; the latter view, the court explained laconically, "cannot be supported as sound law."115

Variance of judicial doctrines, from state to state, matched variance of legislative policies on a wide range of matterseminent domain powers and compensation rules, the terms of land disposal, rights of dispossessed landholders, corporation powers and immunities, banking, labor, and the other areas of law vested under pre-1861 formal-authority allocations in the states-all of which had a major potential upon private-sector institutions and dynamics. From the standpoint of state judiciaries' intransigence on some vital matters of constitutional law, no less than from the perspectives of federal abstention from policy-making and of explicit "decentralizing" Supreme Court doctrines, the structure of formal authority prior to 1861 deviated greatly from what a reading of the basic Marshall Court doctrines would suggest. ${ }^{118}$ The structure of formal authority was one in which constitutent state governments had significant potential power of great scope.

\section{B. Real Power, 1789-1861}

It is one thing to argue, as has been done here, that the way in which formal authority was allocated prior to 1861 laid the

113. Brien v. Williamson, 7 How. 14, 16 (Miss. 1843).

114. Cotton v. Brien, 6 Rob. 115 (La. 1843). See the review of relevant cases in Bramhall v. Beckett, 31 Me. 205, 209 (1850). Mr. Tony Freyer, a fellow of the Harvard Business School, has in progress a major study of $S w i f t v$. Tyson in the context of American commerce and commercial law of the early 19th century.

115. Becker v. Sandusky City Bank, 1 Minn. 311, 319 (1856).

116. In recent years an argument at the other extreme, so to speak, has been made by certain political scientists who assert that federalism was characterized during 1789-1861 (as today) by "sharing" of functions between the state and national governments. This perspective nearly obliterates the problem of centralization versus decentralization by its insistence that "whatever was at the focus of State attention in the 19th century became the recipient of national grants" (i.e. grants-in-aid in land, cash, or loans of personnel). Morton Grodzins, "The Federal System," Goals for Americans (President's Comm'n on Natl. Goals, 1960); the same view is in Daniel Elazar, "The Shaping of Intergovernmental Relations," 359 Annals 11 (1965).

As I think this theory has been shown to be spurious (Scheiber, supra, note 2 , at $2-5$ ), I do not treat it here. 
juridical foundations for a decentralized federalism. It is something else, however, to assess "real power" and how (and at what level) it was exercised in the antebellum Republic. Conclusions as to real power must depend, as was contended above (Section II), upon evidence of the range, intensity, and impact of interventions in the economy actually undertaken by the national and the constituent state governments. Excluded from the following discussion are state policies in such fields as criminal and family law, fields in which real decentralization was extreme but which had only peripheral bearing upon the question of federalism and the economy. ${ }^{117}$ Instead we will hew close to our central concern with federalism as a working system that shaped policymaking processes, the substance of economic policy, and the development of institutions in the private sector.

Interventions in the economy by the national government were limited in range and type; they are well known and require only brief comment here, by way of background to the following discussions of policy at the state level. The main areas of positive Federal action were in the fields of tariff policy, land disposal and management of the public domain, and banking and monetary policies; in addition, the abstentionist policy of allowing virtually free immigration and the awarding of patents for invention also were influential in their effects on the economy's private sector. None of these policies, it should be noted, required extensive cash expenditures or costly administrative overhead; hence there was only limited growth of bureaucracy, and in 1850 the Federal government's civilian employees numbered less than $50,000 .{ }^{118}$ Therefore, the tax impact of Federal governmental activity was minimal in comparison with latterday effects. Land-sale revenues and customs collections, together with a very small revenue from excise taxes, thus sufficed to support the central government's operations.

Federal expenditures were only 2 percent or less of gross national income before 1860 , and so governmental programs had only small redistributive effects on wealth and income. ${ }^{119}$

117. This is not to say that these areas of law were entirely without ramifications affecting the economy or the allocation of scarce public resources. See Lawrence M. Friedman, Contract Law in America, supra, note 28.

118. Paul P. Van Riper, History of the U.S. Civil Service (1958) p. 58. Indicative of the Civil War's enormous impact was the sudden growth of Federal civil employment to over 160,000 while the Southern Confederate central government employed some 70,000 civilians, including slaves. Id. and Harry N. Scheiber, "The Confederate Civil Service," $25 \mathrm{~J}$. So. Hist. 448, 457-58 (1959). Cf. G.A. Lincoln et al., "Mobilization and War," in American Economic History 207, $215 \mathrm{ff}$ (Harris ed. 1961).

119. Paul B. Trescott, "The U.S. Government and National Income, 1790- 
There was nothing comparable to modern redistributive effects of central government operations with levels of Federal expenditures at circa 20 percent of national income or to a national income tax operating on private individuals and corporations. To be sure, the Federal government's grants of land to the states, its building of the National Road, the planning functions of the Army Engineers, and the construction of roads and harbor improvements, removed "bottlenecks" to economic growth and to regional development; and the impact of tariff, immigration and patent policies upon industrial interests was of considerable importance. The fiscal and banking policies of the government periodically had significant influence, as well, upon the timing and intensity of business cycles (again, however, not at anything like the level of magnitude of modern-day policy). ${ }^{120}$ But beyond these policies and their effects, the role of interventionist governmental action in the economy was confined largely to the states' activities. As the following typology of state activities indicates, intervention was varied and went far toward shaping the economic order.

First of all, every state government distributed public largesse to favored individuals, groups and localities. Largesse took several forms, including both tangibles (principally land and cash subsidies) and intangibles (such as legal immunities or special privileges). The most pervasive impact of such distributions was in the privatization of land and other natural resources-that is to say, in governmental policy, universal in all the states, under which land, water, timber, and mineral resources were alienated from public control and placed in private hands. As the numerous scholarly studies of the national government's resource policies have demonstrated, the system was replete with lack of coherence in objectives, with incongruities, and with administrative failure. ${ }^{121}$ Both the objectives and the shortcomings of federal policy were mirrored in the

1860," Trends in the American Economy in the 19th Century (Natl. Bur. of Econ. Research, Studies in Income and Wealth, XXIV, 1960 ); Henry W. Broude, "The Role of the State in American Economic Development 1820-1890," in The State \& Economic Growth (Aitken ed. 1959).

120. As, e.g., during the expansionist business cycle of the mid-1830's. Cf. Harry N. Scheiber, "The Pet Banks in Jacksonian Politics and Finance 1833-41," 23 J. Econ. Hist. 196 (1963), stressing Treasury Department administrative decisions affecting fiscal operations and their impact on banking credit. For an analytic overview of the longer period cf. J.R.T. Hughes and Nathan Rosenberg, "The U.S. Business Cycle before 1860," 15 Econ. Hist. Rev. (2nd ser.) 476 (1963).

121. For analysis and bibliography of state and federal land disposal, cf. Gates, supra, note 5. 
record of the states' disposition of their land and other natural resources. Despite occasional attention to the social objective of maximizing settlement on new farm land, the state land-disposal policies were more generally concerned with producing revenues and with promoting rapid economic growth by extracting resources quickly and at maximum short-term profit. Most states failed to obtain a high return in direct revenue from sale of land, though a handful of states did manage their public domains effectively on this score. So far as developmental goals were concerned, the states' land policies did not apply a conservationist calculus, reckoning long-term social costs and benefits. Instead, the legislatures took the short-term view, which usually favored land speculators and other large-scale capitalist interests such as cattle, lumber, and mining companies. Typically the states acted on a faith that their growth and economic development would best be served by rapid privatization on liberal terms of access and sale. Seldom did state governments make administrative efforts sufficient to assure even probity, let alone systematic "management" and husbanding of their resources. ${ }^{122}$

In the struggle by private interests to obtain largesse, whether of land or of other governmental favors, their pressures on the legislatures tended to be sharply focused. Moreover, it was difficult to resist such pressure because the distribution of largesse admits of fairly easy ramification. That is, repeated trips to the public trough are possible, both for those who come away empty-handed and for those already well fed. If interests $X$ and $Y$ have already been well served-say, by grants of land to aid railroad projects, or by grants of a franchise to build a log boom or millrace dam-similar gifts can be devolved upon $\mathrm{Z}$ the next year. Tangible resources were not unlimited, to be sure: even the largest public domains controlled by individual states were finite, and taxing or borrowing to support cash subsidies could not expand indefinitely. But there was usually abundant room for proliferation of favors; and even the obvious costs in higher taxes did not always serve as an effective deterrent to new cash subsidy commitments in boom periods marked by extreme optimism about the future. ${ }^{123}$

122. Hurst, Law and Economic Growth, at 13-61 (on Wisconsin); David Smith, "Maine and Its Public Domain," in The Frontier in American Development 113-37 (Ellis ed. 1969); Swierenga, supra, note 16, at 51-79; Scheiber, supra, note 17; Harry N. Scheiber, "Land Reform, Speculation, and Governmental Failure," 7 Prologue: J. Natl. Archives 85 (1975) (on Ohio).

123. Largesse distributed by government can be "disaggregated and dispensed unit by small unit;" hence such policy (unlike redistributive or regulatory policy) tends to consist of "highly individualized deci- 
Second, the state governments distributed a wide range of legal privileges and immunities. Like largesse in land or other natural resources, these could be handed out piecemeal and could ramify enormously. The most important type of policy in this category related to franchises given to corporations-tax exemptions, limited liability, and other privileges linked with the basic advantages of corporate owners, separation of management and ownership, and the like. At first, the corporate form was chiefly used for banks, turnpike, bridge and canal companies; but by the 1830 s manufacturing enterprises and by the 1850 s railroads had also assumed central importance.124 As occurred in the scramble for tangible largesse, the struggle to obtain such privileges often had a particularistic local focus. If certain regions of a state, or towns, had won charters for local promoters' bank projects, for instance, then other regions or communities could demand their own as a matter of simple equity. Indeed, there was substantial pressure to make access to such favors general and available to all on equal terms-hence, the general incorporation and general railroad laws of the 1840's and 1850's. ${ }^{125}$

Third, the state governments undertook direct capital investment in the construction and operation of basic transport facilities. From the Revolution to the 1820's, the principal form of transport investment, outside of national funds dedicated to the National Road, was private investment in turnpike roads. Beginning with New York State's fabulously successful Erie Canal project, begun in 1817 and brought to completion in 1825, the leadership in planning and financing of transport innovations shifted to the public sector: the governments of several "public enterprise" states, as they may be termed, built and operated state canal lines that would provide the basic inland transport system of the Middle Atlantic and Old Northwest states. Following close upon New York's lead, and emulating its organization and financing tactics, were Pennsylvania and Ohio; meanwhile Maryland offered massive state aid to a chartered company, the Chesapeake \& Ohio Canal corporation. ${ }^{126}$ As the economy entered

sions." Theodore J. Lowi, "American Business, Public Policy, CaseStudies, and Political Theory," 16 World Politics 677, 689-90 (1964).

124. See, inter alia, Hurst, Legitimacy of the Business Corporation, supra, note 28.

125. Id. at 34-38 et passim; also, Friedman, supra, note 18, ch. 3; Scheiber, Ohio Canal Era, at 271-290; and, on the history of the movement for general incorporation laws, Walter Hugins, Jacksonian Democracy and the Working Class (1960); and Edward Pessen, Jacksonian America (1969). Cf., inter alia, Edwin M. Dodd, American Business Corporations Until 1860 with Special Reference to Massachusetts (1954).

126. The early history of turnpikes and other public and private transport investment may be followed in Curtis P. Nettels, The Emer- 
a boom period in the mid-1830s, other states joined the ranks of these public enterprise leaders: Indiana, Illinois, and Michigan all became committed to comprehensive programs of public transport works, while the original canal states ambitiously, and in some cases recklessly, expanded their projects. ${ }^{127}$ Hence by 1848 the entire Old Northwest region, except Wisconsin (which developed late), was interlaced with canal lines linking the Great Lakes basin with the Ohio-Mississippi River system. New York State vastly increased its canal mileage with branch lines, and new projects were also undertaken in Pennsylvania. The result was the Transportation Revolution's "second phase," in which multiple, alternative export routes to the seaboard were opened up for farmers in the interior regions. Consequently competition for trade among the canal routes brought a major decline in shipping rates and.in state canal tolls (consequently, too, a relative decline in state revenues with which to support debts incurred to build the canals). ${ }^{128}$

By the time this competition-intensified further by the massive increase in steamboat tonnage on the western rivershad peaked during 1849-52, the focus of transport promotion had shifted once again, this time into the private sector where extensive railroad construction was being financed. Not only through liberal corporate charters and the grant of tax exemptions and other immunities, already mentioned, to private railroad promoters, but also through large infusions of public funds in the form of state and municipal aid to the railroad projects, the states continued to play a determinative role in shaping and pacing basic transport development. By comparison, the role of the national government was minor: Federal Army engineers were loaned to private companies; Congress continued to grant funds for river and harbor improvements; and in 1850 the Illinois Central land grant act inaugurated a new phase in federal transport aid, which after a twelve-year hiatus would assume more impressive dimensions in the transcontinental land grants of the

gence of a National Economy 1775-1815 ch. 12 (1962); and George Rogers Taylor, The Transportation Revolution 1815-1860, chs. 2-3 (1951).

127. Goodrich, supra, note 4. The following is an estimate, based on observed data and on allocation procedures, of canal investment to 1860: $1815-34$, total investment $\$ 58.6$ million, of which $70.3 \%$ was public; $1834-44$, total $\$ 72.2$ million, of which $79.4 \%$ was public; and 1844-60, \$57.4 million total, of which $66.3 \%$ was public. Source: Harvey Segal, "Cycles of Canal Construction," in Canals and American Economic Development 215 (Goodrich ed. 1962).

128. Scheiber, Ohio Canal Era, ch. 9 treats the Transportation Revolution's "second phase." See also James Mak and Gary M. Walton, "Steamboats and the Great Productivity Surge in River Transportation," 32 J. Econ. Hist. 619 (1972). 
Civil War years. ${ }^{129}$ But the locus of policy-making activity, clearly, was decentralized.

In the states that undertook major canal programs earlynotably New York, Ohio, and Pennsylvania in the 1820s-the policy process assumed a distinctive style. These states were engaged in an unprecedented effort to raise public loan funds on a scale comparable only to the Revolutionary and War of 1812 financing. Moreover, their projects required numbers of personnel and administrative structures entirely without civilian precedent, utterly dwarfing anything the states had supported in the way of bureaucracies before. Hence the public enterprise states faced severe, concrete limitations and constraints-at least at first. Their policy decisions therefore tended to be deliberative and informed by expert investigations and planning, albeit a cruder form of planning than we have come to expect from the more developed governments of the 20th century United States. Choices of where to place funds and build the lines were based on cost-benefit analysis; the options tended to be articulated fully and debated in great detail. ${ }^{130}$ Hence the public enterprise states did not conform to the model that Hurst has postulated for Wisconsin, where no massive public investment for transport was forthcoming and where the categories of state intervention were cheaply enforced and required little direct administration by bureaucracies. ${ }^{131}$ Even in the public enterprise states, however, the initial success of the canal programs intensified pressure for proliferation and expansion, to reach the areas initially bypassed. Rational planning broke down in the mid-thirties. The result was much like what Massachusetts experienced in its corporation-chartering policy in the $1820 \mathrm{~s}$, when the legislature began to yield to special-interest pressures and greatly ramified the franchises and privileges it was willing to hand out.132

129. Hill, supra, note 6 treats the Army Engineers' role in conducting surveys; Paul W. Gates, The Illinois Central Railroad and its Colonization Work (1934) treats the 1850 grant. During 1852-57 Congress granted land to ten states, which in turn granted it to over forty railroads. Cf. Taylor, supra, note 126 , at 96 . On the rivers, cf. Isaac Lippincott, "A History of River Improvement," $22 \mathrm{~J}$. Pol. Econ. 630 (1914).

130. Scheiber, Ohio Canal Era, chs. 1-3; Miller, supra, note 6; Hartz, supra, note 4 .

131. I have considered this more fully in my article "Government and the Economy," supra, note 4 at 137-43.

132. Cf. Handlin \& Handlin, supra, note 4 at $180-181,224$. That pressures on the state governments were particularly effective because state administration was "underdeveloped" is argued in Goodrich, "American Development Policy: The Case of Internal Improvements," 16 J. Econ. Hist. 456-57 (1956). 
The foregoing analysis of the Transportation Revolution as it took divergent paths and evoked differing styles of policy process and public administration illustrates a key element of decentralization before 1861: there were enormous variations among the states, while the states as a whole-the constituent governments in the federal structure-were the locus of planning and the arena in which the formative policy decisions were being made. In the southern states, too, there was diversity of policy and style within a matrix of less solid commitment to putting public resources into transportation development. Some states, most notably Virginia, Georgia, and Louisiana, did undertake ambitious programs, whereas others adopted only fragmentary aid and minor projects. ${ }^{133}$ This added further to the range of diversities within the framework of a working federalism. So did the early history of the railroads in the $1850 \mathrm{~s}$, when again there was variation as to policy between the states-by now playing a lesser role, though establishing the basic legal framework for private investment against a background of continuing Congressional abstention. ${ }^{134}$

Promotional and public-investment activity comprised only one part of the states' role in transportation. Equally crucial was the practice of every public enterprise state involving the setting of discriminatory tolls on the canal lines they operated. As the canal commissioners in Ohio explained the practice:

Each State finds a justification on the score of interest, in furnishing to its own citizens the cheapest transportation of the surplus products of its industry to a market; while, as a rule of compensation and revenue, the importations [from out of state] are burdened with as heavy a tax as their value will bear. ${ }^{135}$

Reflecting the rivalistic state mercantilism that served as the rationale for public transport in the first place, the canal tolls were frequently adjusted by state officials-who had a wide discretion in this area of policy-to offset the effects of rate discrimination in other states, or to attract traffic from competing

133. On Virginia, which pioneered in "mixed enterprise," see Goodrich, "The Virginia System. . State Planning of Internal Improvements," 64 Pol. Sci. Q. 355 (1949); on Louisiana, Merle Reed, New Orleans and the Railroads: The Struggle for Commercial Empire 1830-1860 (1966); and on other southern states, Goodrich, supra note 4.

134. The enormous diversity, from one state to another, in railroad policies may be traced in Goodrich, supra note 4; Taylor, supra note 81, ch. 5 ; and the monographs on individual states. A particularly rich treatment of railroad policy in its many dimensions is provided by Hurst, Law and Economic Growth, at 270-281.

135. Ohio report of 1848, quoted in Scheiber, Ohio Canal Era at 254-55. Id., chs. 10-11, treats market allocation and state rate-making generally. 
routes. Withal, the rate-making powers of the states resulted in allocation of local markets, significant barriers to free internal commerce, and still further effective decentralization of real power. This was so despite the mandates of Marshall's Supreme Court.

Fourth, in this discussion of state policies, we must consider the role of judge-made and statutory law in defining property rights. As was noted in the discussion of formal authority, above, the central government left wide discretion to the states in formulating the law of property. Largely through the initiatives of judges, but also to some degree through action by the legislatures, the state governments tended to establish (and change) doctrines of property law in ways that served to fix economic priorities and allocate or reallocate resources. Thus, on the Atlantic seaboard in the early decades of the 19th century, there was extensive adjudication of riparian rights. The eastern rivers, in those days, were rich in salmon and other fish, and occasionally legislatures acted to force the removal of dams or other structures that interfered with the fisheries. Hence the courts had to define with great precision the relative rights of the public to fish and of riparian owners to affect water flow. ${ }^{136}$ Elsewhere, the legislatures and courts approved the devolution of eminent domain powers upon entrepreneurs who built drainage projects that made incursions on the rights of abutting landowners. ${ }^{137}$ Where the power of eminent domain came into play, the courts authorized takings but required payment of just compensation (except in South Carolina, where outright expropriation of public roads apparently prevailed). ${ }^{138}$ As judges actually defined it, however, "just compensation" often proved to involve very small payments indeed. In this manner, the fiscal burdens of expediting innovation fell hard upon injured third parties, whose rights were forced to yield.

136. Scheiber, "Road to Munn," supra, note 12, at 336-343; Horwitz, supra, note 13, at 251-62; Angell, $A$ Treatise on the Law of Watercourses 547-65 (5th ed. 1854); Anon., "The Law of Water Privilege," 2 Am. Jurist \& Law Mag. 25-38 (1829).

137. In New Jersey, e.g., meadow-owners had maintained facilities under a colonial act of 1760 for nearly a century when the state challenged their standing. Glover v. Powell, 2 Stockton 211, 229 (N.J. Chanc., 1854).

138. Scheiber, "Road to Munn," supra, note 12, at 364-65; Commonwealth v. Coombs, 2 Mass. 489 (1807); Singleton v. Commissioners, 2 Nott \& McC. 526, 528 (S.C. 1820); State v. Dawson, 3 Hill 428, 431 (S.C. 1835). Pennsylvania constituted a special case in the early national period of eminent domain law, as colonial land grants from William Penn had included gratis 6 per cent surplus acreage. This was intended, in effect, as advance compensation for any property that might be taken for roads. Cf. McClenachan v. Curwin, 3 Yeates 362 (Pa., 1802); and discussion in William B. Stoebuck, "A General Theory of Eminent Domain," 47 Wash. L. Rev. 553, 558-59 (1972). 
In the 1820 s and 1830 s eminent domain law became an important instrument for expediting the construction of canals, especially in the public enterprise states of New York, Ohio, and Pennsylvania. The courts built extraordinary supportive (costreducing) doctrines into the eminent domain power, recognizing that a major project such as the Erie Canal was (in Chancellor Kent's words) “a great public object, calculated to intimidate by its novelty, its expense, and its magnitude."140 Therefore, state officials who engaged in takings or construction work were given tort immunity; and aggrieved property owners were confined to statutory remedies, with the traditional equitable remedies under nuisance, trespass, and damage law foreclosed to them. Moreover, the courts in some states adopted a doctrine of compensation only for actual physical takings, excluding "consequential" damages from the compensability requirement. And in many jurisdictions, the courts also adopted a doctrine of "offsetting benefits," under which alleged benefits of a public project to landowners were offset, in arriving at damage judgments, against the value of property taken from them to build such projects. ${ }^{141}$

Most extraordinary of all was the fact that in every state, regardless of variations in the specifics of doctrine, the very large powers of eminent domain-enhanced by cost-reducing doctrines such as offsetting - were transferred wholesale to the private sector. Thus, in every state the power of eminent domain was devolved upon turnpike, bridge, canal, and railroad companies operating under chartered franchises. This was justified on grounds that such transport companies were vested with a "public purpose." But in the 1850 s and $1860 \mathrm{~s}$, the doctrine of public purpose was expanded further-on the foundation that dated from colonial milldam statutes-to authorize private companies to expropriate property under eminent domain for the construction of manufacturing plants, wharves and basins, log booms, ferries, and water works. ${ }^{142}$ In California, moreover, the basic precepts of eminent domain law were applied to the mining interests, as miners were authorized to enter and take the property of agriculturists in order to prospect for or extract mineral wealth. ${ }^{143}$

140. Rogers v. Bradshaw, 20 John R. 735, 740 (N.Y. 1823).

141. See citations in note 139 , supra.

142. Thayer, supra, note 93; Scheiber, "Road to Munn," supra, note 13, at 367-68.

143. Scheiber and McCurdy, supra, note 15, at 112-30. 
In sum, the eminent domain power and its manifold uses gave rise in the state courts to a doctrine "that the lands of individuals are holden subject to the requisitions of the public exigencies."144 It was, moreover, up to the state, under its sovereign powers, "to judge when public necessity demands a surrender of private property," 145 or, as another court more expansively declared, to authorize takings "not only where the safety, but also where the interest or even the expediency of the state is concerned."148 What the courts of all the states held in common was the pragmatic view that property rights must yield to the public interest; they subscribed generally to an instrumental view-hostile to the notion of inviolable private rights in property, receptive to innovation and enterprise. For purposes of understanding federalism as a working system, however, the course of property law in the states reminds us that each jurisdiction not only enjoyed formal authority to formulate property rules; but each jurisdiction also used that authority vigorously, creatively, and sometimes almost ruthlessly. It was often at the expense of small property owners and to the advantage of large-scale capitalist organizations engaged in building milldams, railroads, and similar undertakings.

Finally, the state governments intervened in the economy to fashion the legal environment of enterprise through the traditional powers of taxation and police. Thus, in the ordering of society to assure public order, health, and welfare, the states were the significant locus not only of formal authority but also of real power, vigorously exercised. ${ }^{147}$

144. Boston \& Roxbury Mill Dam Corp. v. Newman, 12 Pick. 467, 480 (Mass. 1832).

145. Sinnickson v. Johnson, 2 Harr. 129, 141 (N.J. Sup. Ct. 1839).

146. Beekman v. Saratoga \& Sch. Railroad, 3 Paige 45,73 (N.Y. Chanc. 1831). Cf. Scudder v. Trenton \& Del. Falls Co., 1 N.J. Eq. 694 (1832), that "the ever varying condition of society is constantly presenting new objects of public importance and utility; and what shall be considered a public use or benefit, may depend somewhat on the situation and wants of the community for the time being." [Emphasis added.] New York State early drew the line against the legislature's developing of eminent domain powers on private parties to expedite their building of "private roads" (not open to the public); Pennsylvania law moved the other way, authorizing such takings. Taylor v. Porter, Hill 140, 142 (N.Y. 1843); Harvey v. Thomas, 10 Watts 63, 143 (Pa., 1840); cf. Edward S. Corwin, "Due Process of Law before the Civil War," American Constitutional History: Essays 46, 50-51. (Mason \& Garvey eds. 1964). The conflicting rules in New York and Pennsylvania were the subject of an influential and much-studied article, Anon., "The Security of Private Property," 1 Am. Law Mag. 318 (1843); it is analyzed at length in Howard J. Graham, "Procedure to Substance: Extrajudicial Rise of Due Process 1830-1860," Everyman's Constitution 242, 260-63 (1968).

147. Friedman, supra, note 18, chs. 3, 5-6; Levy, supra note 21 , chs. 1013; Hurst, Law \& Economic Growth, supra note 4, Pt. III; Bray Hammond, Banks and Politics in America from the Revolution to the Civil War, passim (1957). 


\section{C. "Federal Effects," 1789-1861}

The kind of decentralized uses of power that we have reviewed here depended upon the federal structure of government: Each state had its own particular "mix" of public policy, with preferences for one interest or another, and with its own set of rules in the establishment of priorities for economic development. American federalism was thus a kind of mosaic: each constituent element had its own coloration and design. The national legal environment in which business operated had its broad boundaries etched by federal constitutional doctrine on such basic issues as contract sanctity and the commerce power; but in many other vital respects the legal environment consisted of the diverse mix of policy in each of the several states. Hence Justice Story asserted that a federal judge had to cope with "the jurisprudence of twenty-four states, essentially differing in habits, laws, institutions, and principles of decision."148 Similarly when a federal bankruptcy law was debated, Congressmen complained that each state had its own distinct system. Hence American businessmen, as Daniel Webster declared, found themselves the servants of "four and twenty masters."149 Such observations were not mere hyperbole. They reflected a contemporary reality-a diffusion of power and lack of centralized policy control regarding an enormous range of governmental functions that in the 20 th century have been coming under national control.

The diffusion of real power in the early 19 th century tended, also, to be self-generating and self-reinforcing. This was so because of the spirit of state mercantilism-the widely shared sense that each state must foster its own economic growth in competition with other states seeking to tap a common pool of potential immigrants, investment capital, and entrepreneurial skills. An initiative by one state would immediately raise the possibility of either competing or emulative responses by others. How the Erie Canal project of New York inspired emulation by other seaboard states-also inspiring complementary projects in the western states, to extend the water transport system from New York into the Ohio-Mississippi Valley-is the best known

148. Joseph Story, "Life of Chief Justice Marshall," 6 Am. Law Mag. 294 (1846); essentially the same article appeared as An Address by Mr. Justice Story on Chief Justice Marshall. . . (repr. 1900; the quotation given is from this pamphlet edition at 45-46).

149. Peter J. Coleman, Debtors and Creditors in America: Insolvency, Imprisonment for Debt. and Bankruptcy 1607-1900, 278-79, (1974) quoting Webster in 1827. Another Congressman referred to a kind of "border war" between New York, with its insolvency laws, and Massachusetts, with its attachment laws (quoted Id. at 279). 
case of this type. ${ }^{150}$ But this example had its counterpart in other, more subtle policy initiatives and responses. Thus California's record in the 1850s of extending a panoply of special privileges over the mining interests was an effective refashioning of property law to attract mining investment and enterprise. Other states were not long in following suit. ${ }^{151}$ The same phenomenon-of making a state's basic law receptive to enterprise and short-term profitability of resource extraction-was evident in the lumber industry. ${ }^{152}$ Similarly, during the Civil War the banking and legal-tender policies of California, as the region's leading commercial state, tended to establish the practical outer limits for counterpart policies in the other western states. $^{153}$ And throughout the period of $1830-1861$, all the states that placed strict regulations upon banking practices, or restricted note issues by banks, found that the notes of neighboring states whose banking laws were more "liberal" would tend to flood their own market centers. ${ }^{154}$ Hence, while fostering a spirit of rivalry and competition among the states, federalism set upper bounds upon the policy options that states might practically exercise-and also bounds upon the effectiveness of the policies a state did invoke.

Another fairly common feature of state mercantilism was "anti-foreignism"-manifested not only in popular attitudes arrayed against "outsiders" but also in laws specifically designed to place out-of-state interests at a disadvantage in commerce or land speculation. In some states, there were laws designed to

150. Cf. Julius Rubin, Canal or Railroad? Imitation and Innovation in the Response to the Erie Canal (Amer. Phil. Soc., Transactions, new ser., 51, pt. 7, 1961); Scheiber, Ohio Canal Era, supra, note 4, ch. 1; Goodrich, supra, note 4, chs. 3-4.

151. See Charles McCurdy, "Stephen J. Field and Public Land Law Development in California, 1850-1866: a Case Study of Judicial Resource Allocation in Nineteenth Century America," 10 Law \& Society Review, forthcoming.

152. Hurst, Law \& Economic Growth, supra, note 4, at 53 et passim.

153. Joseph Ellison, "The Currency Question on the Pacific Coast during The Civil War," 16 Miss. Valley Hist. Rev. 50 (1929). In Perry v. Washburn, 20 Calif. 319 (1862), the state court ruled that the national Legal Tender Act did not affect the state's own requirement that local taxes be paid in specie; cf. Lick v. Faulkner, 25 Calif. 404 (1864), ruling on state legislation of 1863 that sought to circumvent the Legal Tender Act regarding private debts. The Perry ruling was upheld in Lane County v. Oregon, 7 Wall. 71 (U.S. 1868); cf. Charles Fairman, Reconstruction and Reunion 1864-88 (Part I) at 701-704 (Oliver Wendell Holmes Devise History of the U.S. Supreme Court, VI, 1971).

154. Cf. George D. Green, Finance and Economic Development in the Old South: Louisiana Banking 1804-1861, at 78 (1972). "Forbidden to issue notes, Iowa private bankers soon responded to demands for the creation of purchasing power by securing control of banks outside the state and circulating such notes through their Iowa offices." Erling A. Erickson, Banking in Frontier Iowa 1836-1865, at 62 (1971). 
prevent "outsider" control of stock-ownership in types of enterprise deemed essential to in-state interests. ${ }^{155}$

Scrambling to compete with other states to attract enterprise and encourage growth, each state was impelled to adopt liberal policies for distribution of largesse or privilege. And, at the same time, rivalistic state mercantilism tended to militate against effective regulatory policies that would have placed firm controls, for well considered and defined "public interest" objectives, upon private enterprise. The balance between government power and private-sector interests became even more unequal in the $1850 \mathrm{~s}$, when the railroads emerged as America's first giant enterprises. Organized across nearly half a continent, aggregating millions in capital, and controlling bureaucracies much larger than those of any state government, the giant railroad firms outdistanced the objective capacity of the states-if, indeed, a political will was present-to exercise controls over them. ${ }^{156}$ Augmenting the federal structure's effects, therefore, was the dynamism of the private sector. Meanwhile, the particularistic pressures of substate localism continued to operate on lawmakers in the states. Demands for state regulation from regions that already enjoyed ample rairoad facilities but were suffering from rate discrimination were overbalanced by another force-demands from "have-not" areas, eager to keep state policy receptive and beneficent and pushing for subsidies in aid of private railroad enterprise. ${ }^{157}$

Recent research by economic historians Lance Davis and John Legler reinforces the historical model postulated here, of highly significant diversities within the American polity. Reconstructing the level of expenditures and receipts of state government in the 19th century, Davis and Leger find major differences to have existed among the nation's regional groupings of states-differences that are not explained satisfactorily by reference to such variables as differential income levels or degree of economic development, but which apparently reflected variant policy choices and preferences. Thus, in the early 1830s, the New

155. See Henderson, supra, note 56, ch. 6. I have in progress a study of "antiforeignism" and its effects in the pre-1860 period.

156. Cf., for example, Frederick Merk, "Eastern Antecedents of the Grangers," 23 Agric. Hist. 1 (1949); Scheiber, Ohio Canal Era, ch. 11. For a few years, New York State-with an enormous interest to protect in the high-revenue-producing Erie Canal-constituted an exception and imposed well-enforced controls on railroad freight operations. Cf. David M. Ellis, "Rivalry between the New York Central and the Erie Canal," 29 N.Y. Hist. 268, 271-76 (1948).

157. Scheiber, Ohio Canal Era, ch. 11; see also Miller, supra, note 7, for data on the 1860 s that illustrate on identical pattern of political forces. 
England states expended an average of 58 to 70 cents per capita, whereas the Middle Atlantic states averaged $\$ 1.81$ to $\$ 2.79$ and the South Atlantic states 42 to 78 cents. Differences by region of similar magnitudes, though with shifting comparative standings, obtained throughout the 19 th century. ${ }^{158}$

In sum, federal structure, competitive mercantilism, and instate political forces served to diffuse and fragment public power. On the one hand, the states acted in diverse ways to foster their economic growth, often favoring particular private interests. On the other hand, it was difficult for the states to establish a meaningful measure of regulatory control over railroads or other emergent corporate interests. The spatial reach of their jurisdictions was too small-even where fear of rival responses by other states did not completely deaden the force of public regulation.

\section{POST-CIVIL WAR TRENDS}

\section{A. Formal Authority}

The balance of power, read in terms of formal authority, shifted markedly in the Civil War years and the period from 1865 to 1910 . The trend was toward centralization, especially as the federal Supreme Court assumed an increasingly important role as censor of state legislation and also handed down doctrines supportive of Congressional policy initiatives preempting areas of concern formerly left entirely to the states.

The most important developments in the realm of formal authority were the constitutional amendments that ended slavery, authorized civil rights legislation, and established the foundations for major judicial interventions under the rubric of the Fourteenth Amendment's due process provisions. In Texas $v$. White, ${ }^{159}$ the Chase court delivered the famous dictum that "The Constitution, in all its provisions, looks to an indestructible Union, composed of indestructible States." The Court established the juridical basis for dealing with the Civil War and Reconstruction policy with its view that secession in 1861 "imposed new duties upon the United States. The first was that of suppressing the Rebellion. The next was that of re-establishing the broken relations of the State with the Union."160 How the Court applied

158. Davis and Legler, "The Government in the American Economy, 1815-1902: A Quantitative Study," 26 J. Econ. Hist. 514, 532-33 et passim (1966).

159. Texas v. White, 7 Wall. 700 (1869).

160. Ibid. at 725. For a full discussion, see Fairman, supra, note 153 , at $628 \mathrm{ff}$. 
the precepts underlying this doctrine of new federal responsibilities in reviewing the thorny issues of Reconstruction legislation lies beyond the purview of this paper. ${ }^{161}$ But while we do not traverse this familiar ground, we do need to isolate some lesser-known aspects of federal jurisprudence, illustrating the long-term trend of 1865-1910 toward centralization of formal authority - but also illustrating some powerful countercurrents.

Commerce clause decisions after 1865 represented a distinct break with the antebellum juridical tradition. Strong echoes of the Taney's Court's solicitude for sovereign state powers, which had validated regulations that impinged on commerce, were heard in a remarkable Supreme Court decision of 1869,162 upholding discriminatory taxation against out-of-state corporations. As the corporation was "the mere creation of local law," the Court held, the states might properly

exclude the foreign [out-of-state] corporation entirely; they may restrict its business to particular localities or they may exact such security for the performance of its contracts with their citizens as will . . . best promote the public interest. The whole matter rests in their discretion. ${ }^{163}$

In subsequent years, however, the Court modified this doctrine. Instead, it strongly asserted the federal power of judicial review in cases involving discriminatory taxation; and it gave new life to the concept of Congress's "dormant power" to regulate interstate commerce, as a barrier to harmful state actions. ${ }^{164}$ Moreover, beginning in 1886 the Court held that only Congress might properly regulate the rates and operating practices of railroads in a manner directly affecting their interstate operations. ${ }^{165} \mathrm{~A}$ few years earlier, the Court had also moved to make the allocation of formal authority consonant with changing technology in electronic communications, ruling in Pensacola Telegraph Co. $v$.

161. Fairman, supra, note 153, is the fullest scholarly discussion of these issues. For a brilliant analysis of the Civil War and Reconstruction questions as they affected American federalism, see Harold M. Hyman, A More Perfect Union: The Impact of Civil War and Reconstruction on the Constitution (1973). Stanley I. Kutler, Judicial Power and Reconstruction Politics (1968) is a seminal work, but of narrower scope.

162. Paul v. Virginia, 8 Wall. 168 (1869).

163. Id. at 181 .

164. Cf. Corwin, supra, note 97, at 170ff.; Hyman, supra, note 161, at 398ff.; John Roche, "Entrepreneurial Liberty and the Commerce Power," 30 U. Chi. L. Rev. 691 (1963); F.D.G. Ribble, State and National Power over Commerce 81-85 (1937) et passim. Charles McCurdy's doctoral dissertation on Stephen J. Field (in progress, Univ. of Calif., San Diego) contains an incisive analysis of the commerce power.

165. Wabash, St. Louis \& Pac. Railway Co. v. Illinois, 118 U.S. 557 (1886). This landmark decision reversed earlier doctrine; see text at n. 180 , infra. 
Western Union ${ }^{166}$ that the federal commerce power must be deemed adequate to effect national regulation over an innovation that "has changed the habits of business and become one of the necessities of commerce." Thus the Court upheld a Congressional statute and invalidated a conflicting state law that attempted to award a telegraph monopoly within its borders. The national government, the Court declared,

within the scope of its powers, operates on every foot of territory under its jurisdiction. It legislates for the whole nation, and is not embarrassed by State lines. Its peculiar duty is to protect one part of the country from encroachments by another upon the national rights which belong to all.167

By such doctrines, the federal judiciary extended the formal authority of Congress at the expense of the states, despite the intense pressures from below, well expressed in 1883 by a justice of the Illinois supreme court:

If such bodies [business corporations] can not be controlled ... then the powers of government have been subverted and the states virtually destroyed, and they have become useless and expensive appendages to our governmental system.168

In the last decade of the 19th century, moreover, Congress acted upon its newly buttressed formal authority to nationalize regulation of lotteries, the liquor traffic, and traffic in game taken in violation of state laws. ${ }^{160}$

Another centralizing doctrine of major import arose from the concept of a "general jurisprudence"-a concept derivative from Justice Story's rationale for asserting a federal common law in his Swift $v$. Tyson decision of $1842 . .^{170}$ The postwar Supreme Court resorted to the notion of general jurisprudence when, in Pine Grove Township $v$. Talcott $(1874),{ }^{171}$ it departed from its

166. Pensacola Telegraph Co. v. Western Union, 96 U.S. 1 (1877). Cf. Charles Fairman, "What Makes a Great Justice?" 30 B.U.L. Rev. 49, 68 (1950); Henderson, supra, note 56, at 114-16 (that it was with this case "that the real struggle between state transportation monopolies and the Commerce Clause took place"); Hyman, supra, note 161 , at 407-409.

167. Pensacola Telegraph Co. v. Western Union, 96 U.S. 1,9 (1877).

168. Wabash Railroad v. People, 105 III. 236, 239 (1883) (Walker, J., concurring).

169. See Louis W. Koenig, "Federal and State Cooperation under the Constitution," 36 Mich. L. Rev. 752, 759-60 (1938); Jos. E. Kallenbach, Federal Cooperation with the States Under the Commerce Clause (14 Univ. of Michigan Publications: History \& Political Science, 1942).

170. Supra, note 110. Also, Mitchell Wendell, Relations Between the Federal and State Courts, 150ff., esp. at 153. (Columbia Univ. Studies in the Social Sciences, No. 555, 1949, repr. 1968).

171. Pine Grove Township v. Talcott, 19 Wall. 666 (1873). In Gelpcke v. Dubuque, I Wall. 175 (1863), a decade earlier, the Court ruled that contracts valid under prevailing state-court rulings would have to be honored (under the federal contract clause) even if state judicial rules were later changed. Like the Pine Grove decision of 1874, Gelpcke involved bond issues in aid of railroad projects. There fol- 
earlier practice of accepting state court's determinations as to the validity (under the state constitutions) of public aid to railroads. Overturning a Michigan supreme court decision which had invalidated railroad-aid bonds, the Court ruled that where "commercial securities are involved" and sold in a wide market, and where a matter of overarching concern in the economyhere, the matter of public aid to railroads-was in question, federal courts could not bind themselves to honor the rulings in individual states. To be sure, the decision in Pine Grove rested in part on familiar, instrumental rationales. Thus the court explicitly recognized the crucial economic importance of railroads, which "animate the sources of properity, and minister to the growth of cities and towns."172 But the instrumentalism so expressed was harnessed to a new judicial formalism, fraught with potential consequences for constitutional doctrine. For the concept of a "general jurisprudence" was an abstraction that could easily be shaped to accommodate conservative, propertyminded notions of "implied limitations" upon legislative action. Ironically, it was Justice Cooley of the Michigan court, whose anti-bond-aid decision was overturned in Pine Grove, who in his decisions from the bench and his basic treatise on the issue $^{173}$ laid the conceptual groundwork for conservative judicial activism:

There are certain limitations upon [the taxation] power, not prescribed in express terms by any constitutional provision, but inherent in the subject itself, which attend its exercise under all circumstances, and which are as inflexible and abso-

lowed an intense, six-year confrontation of Iowa's state court with the Supreme Court and lower federal courts. Cf. Wendell, supra, note 170, at 156-159; and Fairman, supra, note 153, at 935ff.; Scheiber, "Road to Munn," supra, note 13, at 391-95.

172. Pine Grove Township v. Talcott, 19 Wall. 666 at 678 (1873). Pine Grove presented the more formal issue of general jurisprudence on a factual foundation not previously confronted by the Supreme Court: for in Michigan there had been no state judicial rule handed down on the validity of railroad bond aid prior to the 1870-71 rulings against the constitutionality of taxation for bond-aid purposes (see cases cited at note 174, infra). Cf. Fairman, supra, note 153, at 1011.

173. Cooley, Treatise on Constitutional Limitations (1868). Cf. Clyde Jacobs, Law Writers and the Courts: The Influence of Thomas $M$. Cooley, Christopher G. Tiedeman, and John F. Dillon (1954); and Alan Jones, "Thomas M. Cooley and the Interstate Commerce Com-" mission: Continuity and Change in the Doctrine of Equal Rights," 81 Pol. Sci. Q. 602, 607-9 (1966), an important revisionist article bringing to light Cooley's belief that state intervention too easily becomes "an instrument whose office is to protect the rich in the advantages they have secured" (quoted, Id. at 608). Similarly, Justice Miller-who also became a proponent of implied limitations on the reach of "public purpose" doctrine in its instrumentalist modefeared that the wealthiest propertied elements, especially railroad investors and directors, gained the benefits of bond-aid subsidies. (Charles Fairman, Mr. Justice Miller and the Supreme Court 1826$189067,207-8,[1939]$ ). To this extent, then, a blanket view of implied limitations as "conservative" in intent and effects must be modified. 
lute in their restraints as if directly imposed in the most positive form of words. 174

How the Court might curb the discretion of state legislatures by applying such notions became clear in Loan Association $v$. Topeka (1874). ${ }^{175}$ In that case, the Court struck down a Kansas statute that had authorized municipal aid to a manufacturing firm, with Justice Miller declaring that "there are limitations on power which grow out of the essential nature of all free governments."178 In subsequent years, the Supreme Court invoked the concept of general jurisprudence (and, increasingly, mobilized the Fourteenth Amendment's due process provisions) to establish new boundaries beyond which the states might not venture in their exercise of eminent domain and police powers, as well as taxation powers. ${ }^{177}$

It took a change in judicial personnel, but no great logical leap, for the Supreme Court to move toward its notorious conservative use, in the $1890 \mathrm{~s}$ and afterwards, of the Fourteenth Amendment as an instrument for invalidation of state regulatory laws. Indeed, the bastard constitutional doctrine of "liberty of contract" bore at least strong genetic marks of a general-jurisprudence paternity. By the end of the century, in any event, the Supreme Court had established a "centralizing" judicial role for itself within the federal system of government, striking down state laws enacted under the police powers. The Fourteenth Amendment and liberty of contract thus provided the juridical means for perpetuating on a new basis some of the major obstacles to effective public regulation of private entrepreneurial

174. People v. Salem, 20 Mich. 452, 473 (1870); also, People v. State Treasurer, 23 Mich. 499 (1871); Thomas v. City, 27 Mich. 320 (1873).

175. Loan Association v. Topeka, 20 Wall. 655 (1874).

176. Id. at 663-64. Scheiber, "Road to Munn," supra, note 13, at 38597, seeks to delineate the interrelationships of judicial rulings on "public purpose" in regulatory law, general jurisprudence, and taxation law.

Fairman, supra, note 153, at 1101, asserts: "That municipal aid was not allowed to spread from railroads to other privately owned enterprises was largely the result" of the Loan Association decision. Fairman's contention must be qualified, however, to take account of the decision in Burlington v. Beasley, 94 U.S. 310 (1877), a case decided at the same time as Munn v. Illinois, 94 U.S. 113 (1877). In Beasley, the Court ruled that a state might authorize public bond aid to subsidize a privately owned gristmill, holding that-like railroads-mills of this sort were "quasi-public" and under the Munn doctrine their tolls were subject to regulation. See Bruce Wyman, "The Law of Public Callings" (Pt. 2) 17 Harv. L. Rev. 217, 219 (1904); and Scheiber, "Road to Munn," supra, note 13, at 397-98.

177. Charles McCurdy, "Justice Field and the Jurisprudence of Government-Business Relations: Some Parameters of Laissez-faire Constitutionalism, 1863-1897," $41 \mathrm{~J}$. Am. Hist. 970, 981ff (1975). Also, Edward S. Corwin, "The Supreme Court and the Fourteenth Amendment," 7 Mich. L. Rev. 643 (1909), and works cited in following note. McCurdy's study provides an entirely fresh reinterpretation of these issues. 
interests that we observed in the pre-Civil War years. Earlier, these obstacles had consisted mainly of the states' inadequate capacity to deal with private interests; now it was a matter of the judicial censorship by the Supreme Court undermining regulatory initiatives at the state level. ${ }^{178}$

Our discussion of formal authority after 1861 has, to this point, dealt with familiar and lesser-known aspects of constitutionalism that tended to centralize power in the federal system. But counter-tendencies also deserve attention, and they were hardly trivial in their character. One major area of constitutional law was that in which the Supreme Court shored up the states' formal authority to control the structure and functions of local government. ${ }^{179}$ Then in Munn $v$. Illinois and the Granger Railroad Cases, decided in 1877, ${ }^{180}$ the Court introduced the doctrine of business "affected with a public interest." It found unexceptionable regulation by the states of private concerns whose activities were such as "to create a common charge or burden upon the citizens" or constituted "a practical monopoly, to which the citizen is compelled to resort."181 Of course, these concepts-which derived from half a century's adjudication of riparian law and "public purpose" doctrine-were only nine years later destined to be abridged and hemmed in by new commerce clause doctrine; ${ }^{182}$ and ultimately they would be attenuated further by the conservative jurisprudence of substantive due process, which had its heyday from the early 1890 s to 1935 . But if they did nothing else, Munn and related decisions reinforced the constitutional underpinnings of state police powers. Even the most doctrinaire property-minded justices, once satisfied that confiscation (as they defined it) would not be allowed to masquerade as regulation, supported the validity of police powers over a large range. ${ }^{183}$

178. Cf. Arnold M. Paul, The Conservative Crisis and the Rule of Law: Attitudes of Bar and Bench 1887-1895 (1960); Sidney Fine, Laissez Faire and the General Welfare State: A Study of Conflict in American Thought 1865-1901, ch. 5 (1956); Walton H. Hamilton, "The Path of Due Process of Law," in The Constitution Reconsidered (Read ed. 1938).

179. Hyman, supra, note 161, at 375-79; Anwar Syed, The Political Theory of American Local Government chs. 3-4 (1966).

180. Munn v. Illinois, 94 U.S. 113 (1877); Chicago, etc. R.R. v. Iowa, 94 U.S. 155 (1877); Peik v. Chicago, etc. R.R., 94 U.S. 164 (1877); Chicago, etc. R.R. v. Ackley, 94 U.S. 179 (1877); Winona \& St. P. R.R. v. Blake, 94 U.S. 180 (1877); Stone v. Wisconsin, 94 U.S. 181 (1877).

181. As described by Justice Bradley, in The Sinking Fund Cases, 99 U.S. 700,747 (1878). Compare the views of Judge Ryan of the Wisconsin court, in A.J. Beitzinger, Edward G. Ryan, Lion of the Law ch. 9 $(1960)$.

182. See text at note 165 , supra.

183. Fine, supra, note 178, at 149-164, 352-362; and McCurdy, supra, note 177 , at $977-81$. 
Another important decentralizing doctrine of the post-Civil War era was elaborated in a series of Supreme Court rulings that each state enjoyed broad power to exclude "foreign" corporations (chartered in other states), or to impose conditions upon such companies' right to do business in the host state. The doctrine had its limitations, to be sure. Thus interstate commerce was protected from discriminatory state legislation against foreign corporations; and so was the freedom of federal contractors to do government-related business. Also, the Court ruled in 1874 that no state might require a foreign corporation to stipulate (as a condition of doing business) that it would not exercise its right to remove suits to federal courts. ${ }^{184}$ Extraordinarily enough, however, the Court also held, in 1887, that a state might expel a foreign corporation that actually exercised its right to remove a suit to federal jurisdiction! And not until after 1906 did the Supreme Court begin to abridge state powers in this area by adopting the new doctrine of "unconstitutional conditions"a doctrine that served to reverse the older rulings in most important respects. ${ }^{184 a}$

Finally, in this admittedly brief list of juridical trends that supported decentralized formal power, the Supreme Court proved extremely hospitable to demands from the states for recognition of their special geographic and economic circumstances. Thus the Court permitted the states to adopt widely veried definitions-through constitutional provisions, statute law, and judicial rulings-of what types of private-sector activities comprised "public purpose" enterprise. The Court recognized the validity of eminent domain takings, so long as the compensation requirement was met, to aid irrigation projects, mining enterprises, and other activities given a high priority by western legislatures; and it approved special-district tax assessments in support of water projects in arid localities, and similar undertak-

184. Insurance Co. v. Morse, 20 Wall. 445 (1874). The exceptional cases of interstate commerce and federal agents are discussed, with citations, in Hooper v. California, 155 U.S. 648, 652 (1894); and Horn Silv. Min. Co. v. New York, 143 U.S. 305, 314-15 (1891).

184a. Doyle v. Continental Ins. Co., 94 U.S. 535 (1877). Cf. Phila. Fire Assoc. v. New York, 119 U.S. 110 (1886), validating the state's power to change the terms upon which it admitted a foreign corporation to do business, in this instance through imposition of a new discriminatory franchise tax. Hooper v. California, 155 U.S. 648 (1894) upheld the state's power to impose any conditions it deemed proper upon the agents of a foreign corporation as well as upon the corporation directly. Post-1906 doctrinal changes are discussed in Henderson, supra, note 56 , at 132ff.; and Robert Hale, "Unconstitutional Conditions and Constitutional Rights," 35 Colum. L. Rev. 321, 329336 et passim (1935). Southern Rwy. v. Greene, 216 U.S. 400 (1909), definitively abridged the authority of a state to impose a discriminatory tax upon a foreign corporation. 
ings. Similarly, the Court did not interfere significantly with the western states' diverse policies as to appropriation versus riparian rights in their water law. ${ }^{185}$ In these respects, robust pragmatism and the old "instrumentalist" style of judicial reasoning were still formidable instruments for the support of diversity under federalism.

\section{B. Real Power and Persistent Decentralization After 1861}

In the Civil War years, the distribution of real power was significantly altered by the enactment of a national banking law, a program of massive land grants to aid transcontinental railroads, passage of the Homestead Act, and other measures. ${ }^{180}$ In the decades that followed, too, the new centralization of power and effective policymaking initiatives in the national government had a major impact on the dynamics of economic change. By the 1870s, the legal environment and the conditions for investment were fundamentally influenced by the railroad land grants, by the national government's debt-management and currency policies, and by Congress's decisions to continue the policy of privatization in the disposal of resources on extraordinarily generous terms in the trans-Mississippi West. In 1887, the first Congressional railroad regulatory law was passed-the beginning of federal-level government-by-commission and of a federal administrative law. In 1890 , the Sherman Act, the first national law for corporate regulation outside the transport sector, went into effect; and in the ensuing decade, Congress undertook major initiatives in the fields of reclamation and conservation. Both through judicial interventions and limited legislative policy, mainly affecting railroad workers, the central government also entered the field of labor law and in some respects dominated

185. Scheiber, supra, note 14, at 247-48. The decision in Transp. Co. v. Chicago, 99 U.S. 635 (1878) reaffirmed tort-immunity and compensation doctrines that were supportive of state authority and effectively reduced costs in eminent domain takings. See also Searl v. School Dist., 133 U.S. 553 (1890). Clark v. Nash, 198 U.S. 361 (1905) reaffirmed in the strongest terms the power of a state to determine "public purpose" and authorize takings, even to benefit a private enterprise so common as farming, if deemed necessary by the state to irrigated agriculture in an arid region. Hairston v. Danv. \& W. R.R., 208 U.S. 598 (1908) reaffirmed the states' power to declare what activities constituted a "public purpose." Cf. Scheiber, supra, note 13, at 12-18; and Miller, "Shaping California Water Law," 55 S. Cal. Q. 9 (1973).

186. Louis M. Hacker, The Course of American Economic Growth and Development 180-92 (1970); Hyman, supra, note 161, at $380-81$; Leonard P. Curry, Blueprint for Modern America: Nonmilitary Legislation of the First Civil War Congress (1968); Harry N. Scheiber, "Economic Change in the Civil War Era," 11' Civil War Hist. 396, 407-11 (1965). 
it. Just after the turn of the century, Congress authorized limited national regulation of the food and drug industries-an effort that necessarily required not only a high level of expertise in government, but also a sizable bureaucracy. In the Progressive era, moreover, the national government extended still further the reach of its power into control of marketing, banking and currency, and railroad operations in the private sector. ${ }^{187}$

Meanwhile a new dimension was given the federal system by an increase in intergovernmental collaboration and genuine sharing of functions. ${ }^{188}$ Cooperation between the federal government and the states was a central element of the Carey Act (1894) program of federal grants for irrigation, which also instituted a policy of requiring the states to submit comprehensive plans for approval by federal officials. ${ }^{189}$ Enlarged intergovernmental cooperation in the exercise of police pwers was also instituted with the Lacey Act of 1900, banning interstate shipment of wild game taken in violation of state laws, and other legislation of 1895 and afterward supporting state laws regulating lotteries and "white slave" traffic. ${ }^{190}$ Programs of cash grantsin-aid were also inaugurated (there were five in 1902, contributing $\$ 3$ million to the states), and in 1911 the policy of matchingfunds requirements, with federal inspection of state operations, was in effect. ${ }^{191}$

The formalization of modern grant-in-aid mechanisms was paralleled by another development, lying outside the formal political structure but nonetheless integral to the operative federal system-the emergence of functional bureaucracies. As both the national and state governments were gradually professionalized, officials with similar functions developed a sense of professional community that cut across intergovernmental

187. Fine, supra, note 178 , chs. 10-11.

188. This paragraph follows closely my Condition of American Federalism, supra, note 2 , at 7 .

189. 28 U.S. Stats. 422 (Aug. 18, 1894). On the Newlands Act, see also note 191 , infra.

190. 31 U.S. Stats. 187 (May 25, 1900) (Lacey Act) ; Lottery Act, 18 U.S. Stats. 963, c.191 (March 2,1895), upheld in Champion v. Ames, 188 U.S. 321 (1903) ; Mann (White Slave Traffic) Act, 36 U.S. Stats. 825 (June 25, 1910); upheld in Caminetti v. U.S., 242 U.S. 470 (1916).

191. Matching funds requirements and federal inspection began with the 1911 Forests Act. On this and on cash grants, cf. Scheiber, supra, note 2, at 7 . Also of signal importance in the new pattern of intergovernmental relations was the 1902 Newlands Act, because it dedicated revenue from land sales in the western states to a Revolving Fund (or Reclamation Fund) that served as an independent source of financing for irrigation and related public works. Cf. Gates, History of Public Land Law Development, supra, note 5, at 654-55. In 1916 the newly enacted program of highway aid elaborated the stateplanning and federal-inspection techniques. See James A. Maxwell, The Fiscal Impact of Federalism in the United States 187 (1946). 
lines and even bridged the public and private sectors. Growth of the agricultural experiment stations, especially after founding of the Extension Service in 1914, simultaneously with growth of research and inspection functions in the Department of Agriculture provided one fertile ground for the nurture of professionalization on these lines. Forestry, reclamation, and geological survey activities of the state and national governments provided another, as did highway development after $1916 .{ }^{192}$

Thus the institutional framework of the public sector, within which private investment and economic development went forward, was marked by centralizing trends. And yet the states continued to exercise a significant role in shaping the legal-institutional framework of growth. In many respects, the working federal system therefore remained significantly decentralized.

First of all, it should be recognized that national regulatory legislation appeared only slowly. The 1887 Interstate Commerce Act, for instance, was passed by Congress more than thirty years after the first state laws for the same purpose were enacted and nearly 20 years after the first "Granger Laws" put real teeth into state railroad regulation. ${ }^{193}$ The Sherman Act came only in 1890 , when the trend in the private sector toward highly concentrated, giant corporations had nearly climaxed $^{194}$ and at a point when old-style industrial capitalism was already giving way to full-blown finance capitalism. In these two critical areas of the economy, at least, the institutional, market, and attitudinal factors that had before 1861 permitted the private sector to outrun government's effective capacity (or will) to impose regulation, all continued to operate in the late nineteenth century. But

192. The effects of professionalization are a main theme in Walter $\mathrm{K}$. Ferguson, Geology and Politics in Frontier Texas 1845-1909 (1969); Nash, supra, note 4, at chs. 9, 11; Oscar E. Anderson, Health of a Nation: Harvey W. Wiley and the Fight for Pure Food (1958); Hays, supra, note 6 , passim. The history of USDA research and professionalization is found in Century of Service: The First 100 Years of the U.S. Dept. of Agriculture (USDA Yearbook 1963); and John M. Gaus and L. O. Wolcott, Public Administration and the U.S. Department of Agriculture (1940).

193. Miller, supra, note 7; Frederick Merk, "Eastern Antecedents of the Grangers," 23 Agric. Hist. 1 (1949), on pro-rata laws of the 1850s; Scheiber, Ohio Canal Era, at ch. 11; Charles Fairman, "The So-Called Granger Cases, Lord Hale, and Justice Bradley," 5 Stan. L. Rev. 587 (1958); Gabriel Kolko, Railroads and Regulation 1877-1916, chs. 1-2 (1965).

194. R. L. Nelson, Merger Movements in American Industry 1895-1956 (1959), on mergers in the 1890s; William Letwin, Law and Economic Policy in America: The Evolution of the Sherman Antitrust Act 5970 (1965), on legislation in the states prior to 1890 . Cf. Alfred D. Chandler, Jr., "The Beginnings of 'Big Business' in American Industry," 33 Bus. Hist. Rev. 1 (1959), for macroeconomic historical analysis of basic changes in the U.S. market that established the conditions for giant corporate enterprise in the late 19th century, and analysis of varied responses by management to these changes. 
when regulatory power was mobilized, it came first at the state level. The intensity of private interests' demands for judicial relief from state-level regulation bears witness to the fact that it could be effective; in any case, business had to test (and to a degree, accept) the constraints that state action imposed.

Second, when we turn to the side of public policy in which the states had always been most active and effective- the promotion of private interests in the name of the "common weal"we discover much the same scene as had prevailed in the preCivil War period. Thus the 1870 s represented the high-water mark of munificent state and local public aid to railroad corporations. As was true earlier, railroad aid was extended in a spirit of localistic and state rivalry: every community seemed ready to mortgage itself to assure its future prosperity by gaining good transportation connections to other markets. ${ }^{195}$ More generally, the states continued to pursue mercantilist-style policy by devolving special powers and immunities on favored types of enterprise as well as continuing to grant selective cash subsidies and tax exemptions. ${ }^{190}$

The intangible contributions to capital formation after 1865 included legislatures' devolution of the power of eminent domain. Indeed, the postwar years found many states, especially in the Far West, greatly extending the range of this policy. Hence we find a vigorous survival of the spirit of instrumentalism-the pragmatic willingness to subordinate vested property rights to the needs of favored types of enterprise that promised greater productivity than older types. The western states were then undergoing early-phase economic development based upon extraction of primary resources. ${ }^{197}$ Lacking sufficient labor and capital to fully exploit their natural-resource base, these states

195. Carter Goodrich, "Local Government Planning of Internal Improvements," 57 Pol. Sci. Q. 411 (1951); Harry H. Pierce, Railroads of New York: A Study of Government Aid 1826-1875 (1953); Edward C. Kirkland, Industry Comes of Age: Business, Labor, and Public Policy 1860-1897, 65-68 (1961).

196. The Supreme Court validated some types of public bond aid to private enterprises, while it ruled that other types were unconstitutional on Fourteenth Amendment grounds. See note 176, supra, on Burlington v. Beasly, 94 U.S. 310 (1877), upholding public aid to mills by Kansas, distinguishing Loan Association v. Topeka, 20 Wall. 655 (1874) (invalidating public aid to an iron-bridge company). Cf. Edward S. Corwin, "Judicial Review in Action," 74 U. Pa. L. Rev. 669 (1926). For analysis of Supreme Court doctrine on eminentdomain-power devolution as another form of aid to private enterprise, cf. Dayton D. McKean, "Constitutional Limitations upon the Power of Eminent Domain," 6 Rocky Mt. L. Rev. 16 (1933).

197. On the vital importance of extractive industries in the West, see Eric Lampard's study "Regional Economic Development, 1870-1950," in Harvey Perloff et al., Regions, Resources, and Economic Development (1960), 138-39, 181, 190. 
shaped their laws of property in ways that dealt harshly with some existing private interests-and, that also dealt heedlessly with long-range conservationist possibilities. Their constitutions, the decisions of their courts, and their statute laws generally reflected the strategy of devolution-the devolving of the expropriation power not only on transportation enterprises, but also upon mining, lumbering, drainage, irrigation, logboom, and wharf companies. Some of the older states in the eastern half of the nation followed suit, though to a more limited degree. ${ }^{198}$ Such transformations in property law-based upon the theoretical legal distinction between ordinary businesses and enterprises that represented a "public purpose"-were, as we have noted, for the most part validated by the Supreme Court. By approving the various uses of eminent domain powers, and also by upholding variations in the principles of riparian laws adopted by western states, the Court thus legitimated perhaps the most important single element of genuine diversity in the economic-policy mix of the individual states of the Union. ${ }^{199}$

Nor did cash grants and eminent-domain devolution comprise the whole corpus of promotional activities at the state level. Other major activities included the award of some fifty million acres of land grants to railroad corporations by state government-an amount equivalent to half the amount received by railroads from Congress; the establishment of state agencies to promote immigration; and the fostering of new research and developmental activities-in mining engineering, geology, fisheries and other industries-designed to provide infrastructural support to the private sector. ${ }^{200}$

Third, even while centralization of formal authority and major elements of overall policymaking power were occurring,

198. Scheiber and McCurdy, supra, note 15, at 112-30; Scheiber, supra, note 14, at 243-48; Gordon M. Bakken, "The Impact of the Colorado State Constitution on Rocky Mountain Constitution Making," 47 Colo. Mag. Hist. 152-175 (1970); Samuel C. Wiel, Water Rights in the Western States, ch. 8 (1911).

199. Samuel C. Wiel, "Fifty Years of Water Law," 50 Harv. L. Rev. 252304 (1936). In Devine v. Los Angeles, 202 U.S. 313 (1906) and Los Angles Farming \& Milling Co. v. Los Angeles, 217 U.S. 217 (1910), the Supreme Court held decisions of the state courts to be final on questions of property right in water, even in disputes deriving from definition of rights while the territory was controlled by a foreign power prior to American conquest. Cf. W.J. Burkey, "The Origin, Growth and Function of the Law of Water Use," 10 Wyo. L. J. 95, 109 (1956). See also Ira G. Clark, "The Elephant Butte Controversy: A Chapter in the Emergence of Federal Water Law," 61 J. Am. Hist. 1006, 1008-14 (1975); and citations in note 185, supra.

200. Nash, supra, note 4; James A. Lake, Law and Mineral Wealth: The Legal Profile of the Wisconsin Mining Industry, ch. 6 (1962); Fred A. Shannon, The Farmer's Last Frontier: Agriculture 1860-1897, 268-270, 272-282 (1963); Gilbert C. Fite, The Farmers' Frontier 1865-1900, 25-29, (1966); Kirkland, supra, note 195, at 143-48. 
the states shared in the general increase in the quantum of regulatory power. At the same time, important subsidy effects were sometimes realized through the workings of the police power (or exemptions from it), just as they had been realized through eminent domain law. Thus in the states dominated by major mining interests, the judiciary reduced mining-operations costs by benevolent rulings on the subject of nuisance and torts. In Pennsylvania, for example, the state court ruled in 1886 that a mining company was not liable for polluting a stream with effluents and debris, even though it destroyed the drinking water supply for residents downstream. "Mere personal inconvenience," the court declared, ". . . must yield to the necessities of a great public industry, which although in the hands of a private corporation, subserves a great public interest."201 Similarly, in California it was fully twenty years before hydraulic goldmining operations in the Sacramento River Basin, which raised the river's flood level thirty feet or more with their debris, were finally held accountable and halted. In the interim, major towns were subjected to flooding, and thousands of farms suffered inundation from a great river that the miners thus held in thrall.202 And as Hurst's Wisconsin studies have shown, in that state the police power was severely attenuated by lack of political will to ensure enforcement: "Since the 19th-century statutes left enforcement wholly decentralized and at the dubious initiative of local prosecutors," Hurst writes, "it is a fair inference that they had little effect."203

Fourth, as the police power and eminent domain examples also illustrate, the federal organization of governance meant that highly important, localized activities such as mining or lumbering were placed in a position to virtually control political power in particular states. This produced what may be termed an enclave effect. The enclave state, or "captive state" dominated by a major economic interest, was already a familiar phenomenon; witness the South's relationships to the large-plantation slaveholding interests in the antebellum period. American society was certainly increasingly pluralistic in its variety of economic interests after 1865; and, as Friedman has shown, the interests tended to become more highly organized and well focused, as well as more defensive and exclusionist in their organizational

201. Penna. Coal Co. v. Sanderson, $113 \mathrm{~Pa} .126,149$ (1886).

202. Woodruff v. North Bloomfield Gravel Min. Co., 18 F. 753 (D. Cal. 1884); cf. Hill v. Standard Min. Co., 12 Idaho 223, 85 P. 907 (1906). The California controversy and its legal history are considered fully in Robert Kelley, Gold vs. Grain: The Hydraulic Mining Controversy in California's Sacramento Valley (1959).

203. Hurst, Law and Economic Growth, at 455. 
tactics. $^{204}$ Yet, federal governmental structure meant that particular state jurisdictions could remain enclaves, largely immune from the moderating influence of minority coalitions that might offset the single dominant interests' power. This was the obverse side of the states as "laboratories," celebrated by Justice Brandeis as enclaves where liberal social and governmental experiments could be conducted, whatever the dominant political orientation of the national legislature.

The enclave phenomenon was especially evident in newer states, as in the mining, lumbering, and grazing states of the West, or where a single railroad interest enjoyed inordinate influence over a state's policies. ${ }^{205}$ Some of these states adopted another variant of police powers used to support, rather than exert truly public control over, major private interests; again, devolution of power (as with eminent domain devolution) was the mechanism employed. The cattle-raising states of the Rocky Mountain region thus resorted to the devolution technique in a novel way: they vested in the private cattlemen's associations the power to frame and enforce rules relating to quarantine, herding, and other vital aspects of their industry's operations. On the model later applied to latter-day variants such as state bar or medical associations, a quasigovernmental standing was thus given officially to a powerful interest group. ${ }^{200}$

Fifth, there was a formal legal parallel to the enclave effects that were lodged in informal political processes: it was the practice of the individual states pressing old constitutional claims and adopting legislation that would generate new pressures on the changing structure of formal authority. Most important in this regard was the states' use of their taxation power to erect

204. Friedman, supra, note 2, at 295-299; Robert Weibe, The Search for Order, $1877-1920$ at $127-132$ (1967).

205. A leading western historian has written of the region's states in the late 19th century: "Within their jurisdictions, the lords of the rails ruled as probably only the Du Ponts have ruled in Delaware or the copper magnates in Montana." Earl Pomeroy, The Pacific Slope: A History of California, Oregon, Washington, Idaho, Utah and Nevada (1965), 99. Cf. James E. Wright, The Politics of Populism (1974).

206. Harold E. Briggs, Frontiers of the Northwest: A History of the Upper Missouri Valley, 269-74 (1940); W. Turrentine Jackson, "The Wyoming Stock Growers' Association," 33 Miss. Valley Hist. Rev. 571 (1947); E.S. Osgood, The Day of the Cattleman, ch. 5 (1929). The Wyoming legislature devolved upon the Stock Growers' Association the power to conduct and oversee the state's annual roundup. Small cattlemen complained that the Association, dominated by the largest ranchers, used the roundup as an instrument not for honest exercise of a public trust so much as for the stealing of unbranded cattle from small operators. In a 19th-century western variant of the currentday shootout over malpractice insurance and oversight of medical standards, the Wyoming people resorted to six-gun and bullwhip. See Sydney B. Spiegel, "Who Were the Cattle Rustlers? A Look at the Johnson County War in Wyoming," 49 Soc. Studies 222 (1958). 
barriers impeding true freedom of interstate commerce. In the interstices left by the Supreme Court's nationalizing doctrines, expressed in commerce clause adjudication, ${ }^{207}$ the states managed to impose various discriminatory taxes and license fees as a means of placing out-of-state competitors to in-state interests at a disadvantage. ${ }^{208}$ Evidence of how far this practice prevailed may be seen in the adoption by Illinois, in 1869, of the "reciprocity" principle in its insurance code. The Illinois law imposed upon "foreign" corporations (chartered in other states), and doing business in Illinois, the same taxes, fines, and license fees as Illinois-based corporations suffered in those foreign corporations' respective home states. ${ }^{209}$ In 1865 New York had enacted a similar law; and Pennsylvania followed suit in 1873 , to retaliate against New York for discriminatory taxation there (as it was seen) against Pennsylvania corporations. Extensive litigation followed, and in 1886 the Supreme Court-over Justice Harlan's objections that "a species of commercial warfare by one state against another" was being legitimated-upheld the constitutionality of such legislation. ${ }^{210}$

The history of Wisconsin's taxation of insurance companies at the turn of the century provides a vivid illustration of how complex might be the consequences of retaliatory tax laws. In 1899 the Wisconsin legislature imposed discriminatory taxes against foreign firms, favoring domestic corporations in the insurance industry. The retaliatory tax law of Illinois was thus set in operation against Wisconsin's largest insurance firm, the Northwestern Mutual, with such adverse effects on the latter corporation that it threw its political influence behind a successful move to repeal Wisconsin's discriminatory law in 1901. During the next decade, the Wisconsin legislature was forced to confront repeatedly the potential impact of retaliatory laws elswhere as it sought to frame new tax laws affecting insurance firms. Predictably enough, the Northwestern Mutual invoked the prospect of competitive disadvantages in its out-of-state business, because of retaliatory policies of other states, as an argument for exextremely low levels of state taxation on insurance firms gen-

207. See text, supra, at notes $164,184$.

208. See, inter alia, Stanley C. Hollander, "Nineteenth Century Antidrummer Legislation in the U.S.," 38 Bus. Hist. Rev. 479 (1964); also McCurdy's dissertation, supra note 164.

209. Ill. Laws 234, § 20 (March 26, 1869), upheld, Ins. Co. v. Swigert, 104 Ill. 653 (1882); see also Ill., Attorney-General, Annual Report 1882 , at 13. Cf. Ducat v. Chicago, 10 Wall. $410(1870)$.

210. Phila. Fire Assoc. v. New York, 119 U.S. 110, 129 (1886); the background is given in Henderson, supra, note 56, at 106-7. 
erally in Wisconsin. ${ }^{210 a}$

Discriminatory taxation, retaliation, and reciprocity were only the most obvious and blatant of the rivalistic policies that many states adopted. Similar principles dominated in the policy regarding new railroad charters in some regions of the country after 1865. Thus one state's legislature refused to give a franchise to any railroad promoters who sought to build on a route that would tend to divert commerce from its own ocean-port cities to competing, out-of-state ports. ${ }^{211}$ And so, even while there was centralization after 1865 of basic public policies affecting investment and the strategies of private enterprise, eliminating some of the virtual balkanization that had prevailed down to the $1850 \mathrm{~s}$, there was still a significant degree of residual autarky within American federalism.

A federal structure with significant decentralization inherently provided two routes of escape for business interests that were "caught" in a particular state's policy of discrimination or stringent regulation. One escape route was lateral. That is, a business could remove its legal domicile or its operating facilities from a "hostile" state to a "benign" one. Offering abundant testimony to the attractions of this option was the large number of corporations that relocated their legal domicile in either New Jersey or Delaware. ${ }^{212}$ Further evidence is provided by the

210a. Spencer L. Kimball, Insurance and Public Policy: A Study in the Legal Implementation of Social and Economic Public Policy, Based on Wisconsin Records, 1835-1959, 260-69 (1960). But cf. Kimball's contention that reciprocity and discrimination in tax law was the exception to the general trend in public policy, so that "after 1900, localism was a submerged factor. ... Id. at 280 . Recently published research by $B$. Michael Pritchett has shown how the western and southern states in fact received fewer benefits (indicated by the location of insurance-company investments and of their premium payments) than did other regions. In response to their contemporary understanding of this phenomenon. southern business spokesmen and insurance commissioners called for laws to require insurance companies to invest their funds in the states where they collected their premiums, in proportion to such collections. Pritchett, "Northern Institutions in Southern Financial History: A Note on Insurance Investments," 41 JNL. So. HIST. 391 (1975). Cf. the polemic by South Carolina's insurance commissioner. Fitz Hugh McMaster, Life Insurance Companies Should be Compelled to Invest in the Securities of those States in which the Funds Originate (1914), copy in Library of Congress.

211. Moger, "Railroad Practices and Policies in Virginia after the Civil War," 59 Va. Mag. Hist. \& Biog. 423, 432ff. (1951). For other vivid evidence of the substate and interstate rivalries that shaped railroad policy in this era, see G. L. Anderson, General William Palmer: A Decade of Railroad Building in Colorado (1936); P. W. Gates, Fifty Million Acres: Conflicts over Kansas Land Policy 1854-1890 (1954); K. L. Bryant, Arthur E. Stilwell: Promoter with a Hunch, ch. 4, (1971); John F. Stover, The Railroads of the South, 1865-1900: $A$ Study in Finance and Control, chs. 6-11, (1955).

212. Hurst, Legitimacy of the Business Corporation, at 69-73; William C. Kessler, "Business Organization and Management," Growth of the American Economy 610 (Williamson ed. 1951); Hans B. Thorelli, The 
history of the cotton textiles industry, which in the 1880s and especially 1890s witnessed the phenomenon of "flight" capital and industry: New England firms opened branch plants in the Southeast or actually removed to that region, attracted by the relatively low taxes, low wage scales, the hostility to unions, and a legal climate that permitted child labor (which constituted 25 per cent of the southeastern mill force, compared to a scant 6 per cent in New England)..$^{213}$

The other escape route provided by federal structure was upward: that is, the private business interest that experienced stringent regulation at the state level could either engage in judicial "forum-shopping" or challenge unfavorable legislation (often successfully) in the Supreme Court. ${ }^{214}$ Or else they could seek legislation from Congress that would supplant state authority with a more benevolent national policy. ${ }^{215}$ That the latter escape route was well traveled is manifest in the history of railroad regulation. Some of the very same railroad managers as had resisted state regulation most intransigently in the 1870 s are found, a decade later, beleaguered by actual or potential declines in profits, joining or even leacing the movement for national regulation. ${ }^{216}$ Similarly, as Herbert Gutman's pioneering studies have shown, corporate managers of national-scale firms often discovered that, in towns where their mines and factories were situated, the local people-including police and judicial officialstended to side with the workers in strikes of the 1870s and 1890s. When local juries failed to convict strike leaders, the corporate managers therefore quickly reached for the alternative of statelevel or national-level intervention.217 Such intervention took

Federal Antitrust Policy: Origination of an American Tradition, 256-58 (1954).

213. Jack Blicksilver, Cotton Manufacturing in the Southeast: An Historical Analysis, 16-20, 28-32 (Georgia State College of Business Administration, Studies in Business and Economics, Bull. \#5, 1959).

214. Text at notes 167-168, supra.

215. See, inter alia, Gabriel Kolko, The Triumph of Conservatism (1963); and Robert Wiebe, Businessmen and Reform (1962).

216. Thus the Senate Committee on Interstate Commerce, considering the Interstate Commerce Act draft bill, reported in January 1886 that it had "found among the leading representatives of the railroad interests an increasing readiness to accept the aid of Congress in working out the solution of the railroad problem." Quoted in Kolko, supra, note 193, at 39. See also Id. at 15-16, 34-44. A similar movement occurred in the insurance industry. Confronted with increasingly severe state regulation, many leading insurance company executives came to favor Federal regulation. Although they won President Theodore Roosevelt to their point of view, and a powerful move was made in Congress to obtain a national law, their campaign was blocked by conservative as well as reform opposition. Morton Kellar, The Life Insurance Enterprise, 1885-1910: A Study in the Limits of Corporate Power 227-42 (1963).

217. Herbert G. Gutman, "The Worker's Search for Power: Labor in the Gilded Age," The Gilded Age: A Reappraisal (Morgan ed. 1963). 
the form of calling in state militia or even the national Army, as also happened at the behest of mining-company managers in the terrible labor wars that wracked the Rocky Mountain copper region some years later. ${ }^{218}$ Judicial intervention from the federal courts was also forthcoming when needed, witness the unprecedented, sweeping Supreme Court decision in the 1894 Pullman Strike case-a decision that placed Eugene V. Debs in prison and ruthlessly broke the structure of the union and strike leadership. ${ }^{219}$ In sum, if powerful corporate interests took full advantage of federalism's enclave effects, to gain subsidies from state governments or to exercise virtually total control over policy in certain states, they also had in hand a ready instrument to counteract the unfavorable effects of decentralized power when their situation dictated such a strategy. ${ }^{220}$

Viewed from the perspective of private capitalistic interests, these types of diversity, decentralization of power, and shifts in the locus of policy decisions, could all be deemed "uncertainties" that hampered orderly investment processes and vitiated the advantages of rational market operations. ${ }^{221}$ But the evidence strongly runs the other way, I think, and indicates that the public economic policies of the 19th century United States clustered heavily on one side of the balance scale. ${ }^{222}$ This was the side that favored private entrepreneurial interests, gave impetus to the growth and power of the large-scale private corporation, and contributed to the dominance of the economy by giant firms which had firmly aligned themselves by the 1890 s with investment-banking and financial interests. Moreover, the evidence from our studies in legal-economic history indicates that American federalism provided a benign framework favoring business

218. Vernon H. Jensen, Heritage of Conflicts Labor Relations in the Nonferrous Metals Industry up to 1930, 23-24, 32, 59 et passim (1950), Rhodri Jeffrey-Jones, "Violence in American History: Plug Uglies in the Progressive Era," 8 Perspectives in Am. Hit. 465, 533 et passim; Philip Taft and Philip Ross, "American Labor Violence: Its Causes. Character, and Outcome," in Violence in America: Historical and Comparative Perspectives, I, 221 (Graham \& Gurr, eds. 1969).

219. In re Debs, 158 U.S. 564 (1894); cf. Paul, supra, note 178, ch. 7.

220. Of course, appeal to the national government for redress of an unfavorable state-level situation was open also to "reform" groups seeking more effective regulation of business interests or seeking uniform national standards as a way around "competition in laxity." Classic examples are the movements for child-labor reform and for national pipeline regulation: Cf. S.B. Wood, Constitutional Politics in the Progressive Era: Child Labor and the Law (1968); Arthur Johnson, The Development of American Petroleum Pipelines, . . . 1862-1906, chs. 9-10 (1956).

221. Cf. Thomas C. Cochran, "The Paradox of American Economic Growth," 61 J. Am. Hist. 925, 934 (1975).

222. The present work is limited to the period up to 1910 . I plan to deal with the modern period in a forthcoming book on the history of American federalism. 
institutions and fostering "benevolent" promotional or supportive policies by rivalistic state governments. Equally important, federalism also threw serious structural obstacles in the way of timely, effective regulation of business by governmental authorities. 